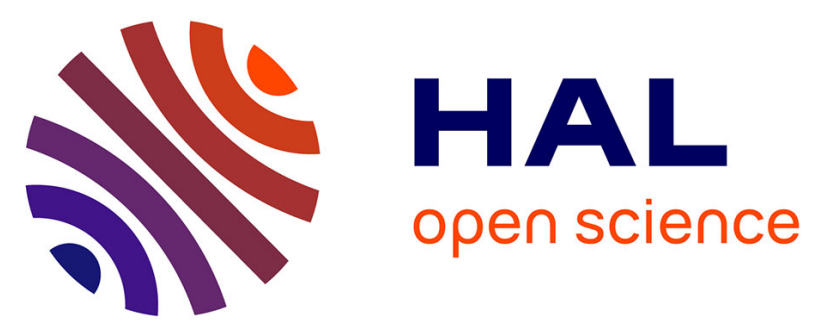

\title{
Bismuth/Silver-Based Two-Dimensional Iodide Double and One-Dimensional Bi Perovskites: Interplay between Structural and Electronic Dimensions
}

Xiaotong Li, Boubacar Traore, Mikael Kepenekian, Linda Li, Constantinos C

Stoumpos, Peijun Guo, Jacky Even, Claudine Katan, Mercouri G Kanatzidis

\section{To cite this version:}

Xiaotong Li, Boubacar Traore, Mikael Kepenekian, Linda Li, Constantinos C Stoumpos, et al.. Bismuth/Silver-Based Two-Dimensional Iodide Double and One-Dimensional Bi Perovskites: Interplay between Structural and Electronic Dimensions. Chemistry of Materials, 2021, 33 (15), pp.6206-6216. 10.1021/acs.chemmater.1c01952 . hal-03299948

\section{HAL Id: hal-03299948 \\ https://hal.science/hal-03299948}

Submitted on 26 Jul 2021

HAL is a multi-disciplinary open access archive for the deposit and dissemination of scientific research documents, whether they are published or not. The documents may come from teaching and research institutions in France or abroad, or from public or private research centers.
L'archive ouverte pluridisciplinaire HAL, est destinée au dépôt et à la diffusion de documents scientifiques de niveau recherche, publiés ou non, émanant des établissements d'enseignement et de recherche français ou étrangers, des laboratoires publics ou privés. 


\title{
Bismuth/Silver-based 2D Iodide Double and 1D Bi Perovskites: Interplay Between Structural and Electronic Dimensions
}

Xiaotong Li ${ }^{\dagger}$ Boubacar Traoré,,$^{\S}{ }^{\S}$ Mikaël Kepenekian, ${ }^{\S}$ Linda Li, ${ }^{\ddagger}$ Constantinos C. Stoumpos, ${ }^{\nabla}$ Peijun Guo, ${ }^{\ddagger}$ Jacky Even,, Claudine Katan, ${ }^{\S}$ and Mercouri G. Kanatzidis ${ }^{*}{ }^{\dagger}$

${ }^{\dagger}$ Department of Chemistry, Northwestern University, Evanston, Illinois 60208, United States "Univ Rennes, INSA Rennes, CNRS, Institut FOTON, UMR 6082, Rennes F-35000, France ${ }^{\S}$ Univ Rennes, ENSCR, INSA Rennes, CNRS, ISCR (Institut des Sciences Chimiques de Rennes), UMR 6226, Rennes F-35000, France

${ }^{ \pm}$Department of Chemical and Environmental Engineering, Yale University, New Haven, Connecticut 06511, United States

Department of Materials Science and Technology, Voutes Campus, University of Crete, Heraklion GR-70013, Greece

\begin{abstract}
New structures with favorable band structure and optical properties are of broad interest to the halide perovskite community. Recently, lead-free two-dimensional (2D) double perovskites have emerged as dimensionally reduced counterparts of their 3D analogues. Besides the structural diversity provided by the organic cation, the achievement of $2 \mathrm{D}$ lead-free iodide double perovskites has attached researchers to explore more structures in this new material family. Here, we report the synthesis and structures of a series of 2D iodide double perovskites based on cyclic diammonium cations (aminomethyl)piperidinium (AMP) and (aminomethyl)pyridinium (AMPY), $(4 \mathrm{AMP})_{2} \mathrm{AgBiI}{ }_{8}$ and $(3 \mathrm{AMPY})_{2} \mathrm{AgBiI} \mathrm{I}_{8}$, and compare them with $1 \mathrm{D}$ structures with Bi only (x$\mathrm{AMP}) \mathrm{BiI}_{5}$ and (x-AMPY)BiI 5 ( $\mathrm{x}=3$ and 4$)$. The crystallographic structures of the double perovskite phases are highly distorted, because of the inability of Ag to form regular octahedral coordination with iodine. The experimental bandgaps of the double perovskite phases are surprisingly similar $\left((4 \mathrm{AMP})_{2} \mathrm{AgBiI} I_{8}\right)$ or even larger $\left((3 \mathrm{AMPY})_{2} \mathrm{AgBiI}_{8}\right)$ than in the $1 \mathrm{D}$ structures with the same cations ((4AMP)BiI 5 and $\left.(3 \mathrm{AMPY}) \mathrm{BiI}_{5}\right)$. DFT calculations suggest that the effective electronic dimensionality of the double perovskites is on par or lower than that of 1D structures. The reduced electronic dimension of the 2D compounds originates from the weak electronic coupling between the corner-sharing Ag and $\mathrm{Bi}$ octahedra. The band structures for the 1D compounds are dispersive in the chain direction, suggesting that their electronic and structural dimensions are similar. Low frequency Raman spectra exhibit distinct peaks at room temperature for all compounds reported here, suggesting rigid lattices.
\end{abstract}


Keywords: 2D iodide double perovskite, 1D Bi perovskite, electronic dimension, optical property 


\section{Introduction}

Two-dimensional (2D) halide perovskites have attracted tremendous research interests thanks to their enhanced stability and broader structural diversity compared to their three-dimensional (3D) analogues. ${ }^{1-3}$ They have been widely explored for optoelectronic applications such as solar cells ${ }^{4-}$ ${ }^{8}$, light-emitting diodes (LEDs) $)^{9}$, detectors ${ }^{10}$ and lasers ${ }^{11}$. 2D halide perovskites based on $\mathrm{Pb}^{2+}$ dominate the field because of their favorable electronic structures thanks to the $\mathrm{Pb} \mathrm{s}{ }^{2}$ lone pair. ${ }^{12}$, ${ }^{13}$ In the efforts to expand the family and in part to eliminate the perceived toxic $\mathrm{Pb}$, researchers have developed the double perovskites where $\mathrm{Pb}^{2+}$ is replaced by a +3 metal (such as $\mathrm{Bi}$ or In) and a +1 metal (such as $\mathrm{Ag}$ or $\mathrm{Cu}$ ). ${ }^{14-16}$ So far, most 3D double perovskites are based on bromide or chloride because of a size limit that excludes the iodide structures. Since the octahedral ratio, $\mu=r\left(M^{I I I}\right) / r(X)$ (where $\mathrm{r}\left(\mathrm{M}^{\mathrm{III}}\right)$ and $\mathrm{r}(\mathrm{X})$ are the radii of the +3 metal and halogen, respectively), needs to be $\geq 0.41$, it places the iodine with its large radius off limits since few +3 metals can meet the requirement. ${ }^{17,} 18$ However, using the dimension reduction ${ }^{19-22}$ as in $\mathrm{Pb}$ based perovskites , 2D iodide double perovskites have been achieved recently ${ }^{23}$. After the first report of iodide 2D double perovskite using aromatic diammonium cations, ${ }^{23}$ they were also synthesized with aliphatic diammonium cations ${ }^{24-26}$ and monoammonium cations ${ }^{25}$, 27. They have demonstrated interesting features such as ferroelectricity, X-ray detection ${ }^{28}$ and even circularly polarized light detection ${ }^{29}$.

One of the limitations of the double perovskite family is their weak optical absorption because of the indirect nature of the bandgap. ${ }^{14,15}$ Another notable concern is that even though they are structurally connected in 3D, their electronic structures suggest lower dimensionality because the +1 transition metal and +3 metal octahedra are disconnected in terms of electronic coupling due to the absence of a lone pair in the transition metal. ${ }^{30}$ The only +1 metals with similar lone pair electronic configuration are $\mathrm{Tl}^{+}$and $\mathrm{In}^{+}$, the former is more toxic than $\mathrm{Pb}^{31}$ and later is subject to oxidation $^{32}$, putting the field into a dilemma.

On the other hand Bi-only halides tend to form 0D structures such as $\mathrm{A}_{3} \mathrm{Bi}_{2} \mathrm{I}_{9}\left(\mathrm{~A}\right.$ is $\mathrm{Cs}^{+}$and methylammonium) which feature molecular dimers of $\left[\mathrm{Bi}_{2} \mathrm{I}_{9}\right]^{3-33}, 1 \mathrm{D}$ chains $\mathrm{A}^{\prime} \mathrm{BiI}_{5}$ ( $\mathrm{A}^{\prime}$ is an organic diammonium cations) $)^{34,35}$ and $2 \mathrm{D}\langle 111\rangle$-oriented $2 \mathrm{D}$ perovskites $\mathrm{A}_{3} \mathrm{Bi}_{2} \mathrm{I}_{9}\left(\mathrm{~A}=\mathrm{NH}_{4}{ }^{+}, \mathrm{K}^{+}\right.$, $\left.\mathrm{Rb}^{+}\right)^{36}$. The last one can also be seen as vacancy ordered double perovskite $\mathrm{A}_{3}\left[\mathrm{Bi}_{2} \square\right] \mathrm{I}_{9}$, where $1 / 3$ of the Bi octahedra are vacant, while the remaining $2 / 3$ of Bi octahedra remain connected by 
corner-sharing. The maintenance of corner-sharing is important to ensure sizeable electronic coupling to get dispersive electronic bands. ${ }^{37}$ Generally edge-sharing and face-sharing $\mathrm{BiI}_{6}$ octahedra form compounds that exhibit flat electronic bands. ${ }^{38}$

The 1D A'BiI 5 structures were first explored by $\mathrm{Mitzi}^{34}$ and Papavassiliou ${ }^{35}$ et al in late 1990s. However, their optical properties and electronic structures were not studied in detail. Here, we report the synthesis and structures of two iodide 2D double perovskites with small cyclic diammonium cations aminomethylpiperidinium (AMP) and aminomethylpyridinium (AMPY) and compare them with the 1D structures with only corner-sharing Bi octahedra. The bandgaps of compounds reported here are between 1.83 and $2.05 \mathrm{eV}$. Band structure calculations suggest that the double perovskite structures present flat electronic bands whereas for the 1D structures, there is some band dispersion along the chain direction. The calculations indicate that there is a weak electronic coupling between the $\mathrm{Ag}$ and $\mathrm{Bi}$ octahedra which gives rise to a lower dimensional electronic structure than that of their structural dimension, emphasizing the importance of understanding the structure-property relationship for determining the proper application for these materials.

\section{Experimental Section}

\section{Synthesis}

$(3 \mathrm{AMPY})_{2} \mathrm{AgBiI}_{8} \cdot \mathrm{H}_{2} \mathrm{O}$. An amount of $0.5 \mathrm{mmol} \mathrm{Bi(}\left(\mathrm{NO}_{3}\right)_{3} \cdot 5 \mathrm{H}_{2} \mathrm{O}(242.6 \mathrm{mg})$ and $2 \mathrm{mml} \mathrm{AgNO}_{3}$ (339.6 mg) were dissolved in $5.5 \mathrm{~mL}$ concentrated $\mathrm{HI}$ under heating at $120^{\circ} \mathrm{C}$ and stirring for 10 min. In a separate vial, $1 \mathrm{mmol} 3 \mathrm{AMPY}$ was added to $1 \mathrm{~mL} \mathrm{H}_{3} \mathrm{PO}_{2}$ solution under stirring. The neutralized 3AMPY was then added to the HI solution under heating and stirring until a clear red solution was obtained. Then the hot plate was turned off and the solution was cooled to room temperature, and red crystals precipitated out in one day. The red crystals were separated by vacuum filtration and dried on the filtration funnel for a further $30 \mathrm{~min}$. Yield: $400.7 \mathrm{mg}, 51.2 \%$ based on total Bi.

$(4 \mathrm{AMP})_{2} \mathrm{AgBiI}{ }_{8} \cdot 0.5 \mathrm{H}_{2} \mathrm{O}$. An amount of $0.5 \mathrm{mmol} \mathrm{Bi}\left(\mathrm{NO}_{3}\right)_{3} \cdot 5 \mathrm{H}_{2} \mathrm{O}(242.6 \mathrm{mg})$ and $2 \mathrm{mml} \mathrm{AgNO}_{3}$ $\left(339.6 \mathrm{mg}\right.$ ) were dissolved in $10 \mathrm{~mL}$ concentrated $\mathrm{HI}$ under heating at $120^{\circ} \mathrm{C}$ and stirring for 10 min. In a separate vial, $1 \mathrm{mmol} 4 \mathrm{AMP}$ was added to $1 \mathrm{~mL} \mathrm{H}_{3} \mathrm{PO}_{2}$ solution under stirring. The neutralized 4AMP was then added to the HI solution under heating and stirring until a clear red solution was obtained. Then the hot plate was turned to $80^{\circ} \mathrm{C}$ and kept at this temperature until 
red crystals started to precipitate out. Then the hot plate was turned off and the solution was cooled to room temperature until the crystals completely precipitated out within one day. The red crystals were separated by vacuum filtration and dried on the filtration funnel for a further 30 min. Yield: $337.0 \mathrm{mg}, 42.8 \%$ based on total Bi.

(3AMP)BiI 5 . An amount of $1 \mathrm{mmol} \mathrm{Bi}\left(\mathrm{NO}_{3}\right)_{3} \cdot 5 \mathrm{H}_{2} \mathrm{O}(485.1 \mathrm{mg})$ was dissolved in $5 \mathrm{~mL}$ concentrated $\mathrm{HI}$ under heating at $120^{\circ} \mathrm{C}$ and stirring for $10 \mathrm{~min}$. In a separate vial, $1 \mathrm{mmol}$ 3AMP was added to $1 \mathrm{~mL} \mathrm{H}_{3} \mathrm{PO}_{2}$ solution under stirring. The neutralized 3AMP was then added to the HI solution under heating and stirring until a clear red solution was obtained. Then the hot plate was turned off and the solution was cooled to room temperature, and dark red crystals precipitated out in one day. The crystals were separated by vacuum filtration and dried on the filtration funnel for a further $30 \mathrm{~min}$. Yield: $543.9 \mathrm{mg}, 56.7 \%$ based on total Bi.

(4AMP)BiI 5 . An amount of $1 \mathrm{mmol} \mathrm{Bi}\left(\mathrm{NO}_{3}\right)_{3} \cdot 5 \mathrm{H}_{2} \mathrm{O}(485.1 \mathrm{mg})$ was dissolved in $10 \mathrm{~mL}$ concentrated $\mathrm{HI}$ under heating at $120^{\circ} \mathrm{C}$ and stirring for $10 \mathrm{~min}$. In a separate vial, $1 \mathrm{mmol}$ 4AMP was added to $1 \mathrm{~mL} \mathrm{H}_{3} \mathrm{PO}_{2}$ solution under stirring. The neutralized 4AMP was then added to the HI solution under heating and stirring until a clear red solution was obtained. Then the hot plate was turned off and the solution was cooled to room temperature, and dark red crystals precipitated out in one day. The crystals were separated by vacuum filtration and dried on the filtration funnel for a further $30 \mathrm{~min}$. Yield: $521.2 \mathrm{mg}, 54.3 \%$ based on total Bi.

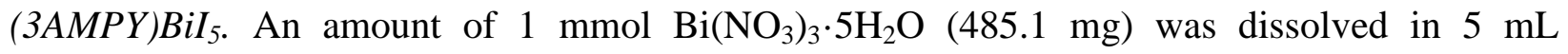
concentrated $\mathrm{HI}$ under heating at $120{ }^{\circ} \mathrm{C}$ and stirring for $10 \mathrm{~min}$. In a separate vial, $1 \mathrm{mmol}$ 3AMPY was added to $1 \mathrm{~mL} \mathrm{H}_{3} \mathrm{PO}_{2}$ solution under stirring. The neutralized 3AMPY was then added to the HI solution under heating and stirring until a clear red solution was obtained. Then the hot plate was turned off and the solution was cooled to room temperature, and dark red crystals precipitated out in one day. The crystals were separated by vacuum filtration and dried on the filtration funnel for a further $30 \mathrm{~min}$. Yield: $400.4 \mathrm{mg}, 42.0 \%$ based on total Bi.

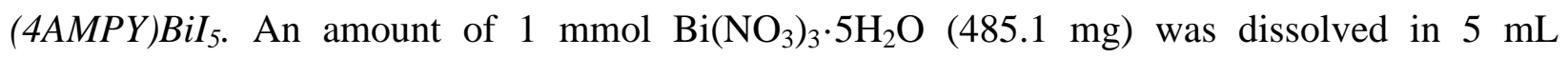
concentrated $\mathrm{HI}$ under heating at $120^{\circ} \mathrm{C}$ and stirring for $10 \mathrm{~min}$. In a separate vial, $1 \mathrm{mmol}$ 4AMPY was added to $1 \mathrm{~mL} \mathrm{H}_{3} \mathrm{PO}_{2}$ solution under stirring. The neutralized 4AMPY was then added to the HI solution under heating and stirring until a clear red solution was obtained. Then the hot plate was turned off and the solution was cooled to room temperature, and dark red 
crystals precipitated out in one day. The crystals were separated by vacuum filtration and dried on the filtration funnel for a further $30 \mathrm{~min}$. Yield: $522.1 \mathrm{mg}, 54.7 \%$ based on total Bi.

\section{Results and Discussion}

Synthesis. All compounds were synthesized from solution using concentrated HI. The synthesis of the $1 \mathrm{D}$ phases used a stoichiometric ratio between the $\mathrm{Bi}\left(\mathrm{NO}_{3}\right)_{3} \cdot 5 \mathrm{H}_{2} \mathrm{O}$ and the cation, and the concentration of the solution was tuned to avoid the precipitation of a second phase. When the solution was too diluted ( $\mathrm{Bi}$ concentration lower than $0.1 \mathrm{~mol} / \mathrm{L}$ ), light-yellow non-perovskite hydrate phase would form. After the starting materials were dissolved upon heating at $120{ }^{\circ} \mathrm{C}$ and stirring, the solution was cooled to room temperature and dark-red, needle-shaped crystals precipitated out within one day. For the synthesis of the double perovskite phase, an excess amount of $\mathrm{AgNO}_{3}$ was used to eliminate the competing 1D phases. When the HI solution is too concentrated, the 1D phases precipitate out first. However, if it is too dilute $(0.05 \mathrm{~mol} / \mathrm{L} \mathrm{Bi})$, a light-yellow non-perovskite phase would come out. Therefore, the concentration was optimized for the double perovskite phase. For $(4 \mathrm{AMP})_{2} \mathrm{AgBiI}_{8} \cdot 0.5 \mathrm{H}_{2} \mathrm{O}$, a step-cooling method was used to increase the crystal quality. The solution was first cooled to $80{ }^{\circ} \mathrm{C}$ and kept at this temperature until crystals started to precipitate out. Then it was cooled to room temperature and needleshaped crystals in dark-red color precipitated out within one hour.

The experimental and calculated powder X-ray diffraction (PXRD) patterns are shown in Figure 1. For the double perovskite structures, the first strong peak shows up right before $2 \theta=10^{\circ}$, corresponding to the $(20 \overline{2})$ and (002) planes for the $(4 \mathrm{AMP})_{2} \mathrm{AgBiI}_{8} \cdot 0.5 \mathrm{H}_{2} \mathrm{O}$ and $(3 \mathrm{AMPY})_{2} \mathrm{AgBiI}_{8} \cdot \mathrm{H}_{2} \mathrm{O}$ structures, respectively. The two peaks correspond to the d-spacings of $9.94 \AA$ and $9.23 \AA$, respectively, and match well with the short interlayer distances. Interestingly, the PXRD patterns of (3AMP)BiI $I_{5}$ and $\left(4 \mathrm{AMPY} \mathrm{BiI}_{5}\right.$ structures look similar to those of the double perovskites, with first strong peaks corresponding to the (101) and (110) planes, respectively. For (4AMP)BiI 5 and (3AMPY)BiI 5 structures, their PXRD can be differentiated from the double perovskite structures only by the small peak around $2 \theta=9^{\circ}$ right before the strong peak $\left(2 \theta=10^{\circ}\right.$.). This suggests that careful single-crystal characterization is needed to determine the structures. 
(a)
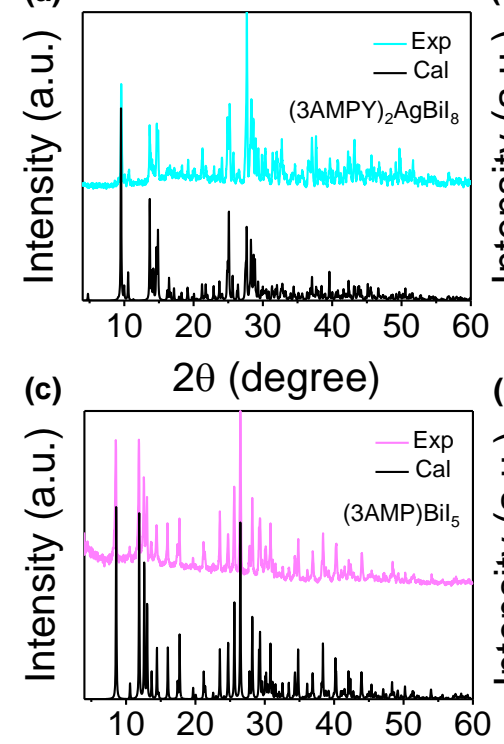

(e) $2 \theta$ (degree)

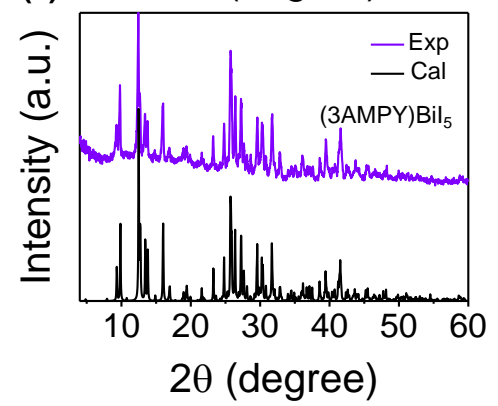

(b)

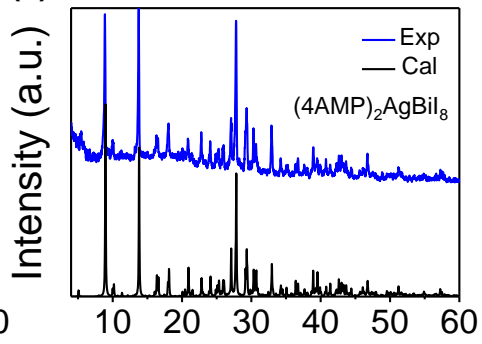

(d) $\quad 2 \theta$ (degree)

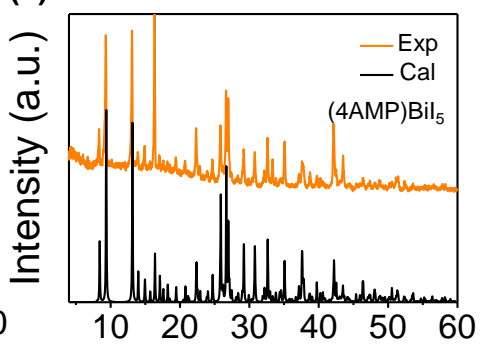

(f) $2 \theta$ (degree)

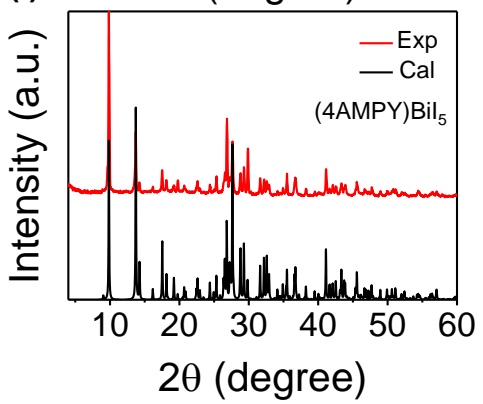

Figure 1. Experimental and calculated PXRD patterns of (a) $(4 \mathrm{AMP})_{2} \mathrm{AgBiI}_{8} \cdot 0.5 \mathrm{H}_{2} \mathrm{O}$, (b) $(3 \mathrm{AMPY})_{2} \mathrm{AgBiI}_{8} \cdot \mathrm{H}_{2} \mathrm{O}$, (c) $(3 \mathrm{AMP}) \mathrm{BiI}_{5}$, (d) $\left(4 \mathrm{AMP}^{\mathrm{B}} \mathrm{BiI}_{5}\right.$, (e) $(3 \mathrm{AMPY}) \mathrm{BiI}_{5}$ and (f) $(4 \mathrm{AMPY}) \mathrm{BiI}_{5}$.

Crystal structures. The $2 \mathrm{D}$ perovskite $(4 \mathrm{AMP})_{2} \mathrm{AgBiI}{ }_{8} \cdot 0.5 \mathrm{H}_{2} \mathrm{O}$ crystallizes in the $C 2 / c$ space group, with the results of structural refinement shown in Table 1, and detailed crystallographic data provided in SI. The structure adopts a large supercell with lattice parameters $a=34.988(7)$ $\AA, b=8.4789(17) \AA$ and $c=22.226(4) \AA$. Even though a smaller cell (subcell $a=21.219(4) \AA, b$ $=8.4789(17) \AA$ and $c=19.558(4) \AA$ ) may also be found and used to solve the structure, it gives rise to poor refinement and disorder of iodine atoms, where the bridging iodine atom is disordered over two symmetry-related sites with an occupancy of 0.5 . However, this disorder is fully resolved in the correct larger unit cell. In an ideal structure, the four adjacent octahedra should make up a square, but since the $\mathrm{MI}_{6}$ octahedra are heavily tilted in-plane, two edges of the square are "pulled-in" and the other two are "pushed-out" (Figure 2a) to introduce a rhombic distortion in the equatorial octahedral plane. The distortion in the inorganic layer is fully ordered. 
Usually in $\mathrm{Pb} 2 \mathrm{D}$ perovskites, the $\mathrm{Pb} \cdots \mathrm{Pb}$ distances in the opposite edges of the square are similar, but different from the other two edges, forming a rectangle with four adjacent octahedra. But for the 2D double perovskite structure, the four adjacent edges ( $\mathrm{Ag} \cdots \mathrm{Bi}$ distances) can be very different, suggesting large anisotropy, which may cause extra strain in the structure (Figure $\mathrm{S} 1)$.

The metal sites are also ordered with $\mathrm{Ag}^{\mathrm{I}}$ and $\mathrm{Bi}^{\mathrm{III}}$ alternating with each other (Figure $2 \mathrm{~b}$ ). The octahedral coordination environments, however, are quite different for $\mathrm{Ag}^{\mathrm{I}}$ and $\mathrm{Bi}^{\mathrm{III}}$. For $\mathrm{Bi}^{\mathrm{III}}$, the octahedra are regular with uniform Bi-I bond lengths. The $\mathrm{Ag}^{\mathrm{I}}$ local environment is much more distorted, and the Ag-I bond lengths vary from 2.6524(8) $\AA$ in the axial position to $3.823(8) \AA$ in the equatorial plane, with the Ag-I bonds in the in-plane direction being much longer than those in the out-of-plane direction (Table 3).

We can calculate the distortion index (D) using the equation, $D=\frac{1}{6} \sum_{i}^{6} \frac{\left|l_{i}-l_{a v}\right|}{l_{a v}}$, where $1_{i}$ and $1_{\mathrm{av}}$ are the individual and average M-I bond lengths, and the $\mathrm{D}$ value for the $\mathrm{Ag}^{\mathrm{I}}$ and $\mathrm{Bi}^{\mathrm{III}}$ sites are 0.109 and 0.026, respectively. This suggests that $\mathrm{Ag}^{\mathrm{I}}$ is much less prone to form regular octahedral coordination with iodine, which is part of the reason why iodide double perovskites are rare. More interestingly, the organic cations are also ordered, and their configuration is identified by the charge density of $\mathrm{C}$ and $\mathrm{N}$ atoms (Figure 2c). This is different from the iodide $2 \mathrm{D}$ double perovskite with aromatic spacer cation, $(\mathrm{AE} 2 \mathrm{~T})_{2} \mathrm{AgBiI} \mathrm{I}_{8}\left(\mathrm{AE} 2 \mathrm{~T}=5,5^{\prime}-\right.$ diylbis(aminoethyl)-[2,2'-bithiophene]), where the carbon and nitrogen atoms are disordered. ${ }^{23}$

The disordered organic cations AE2T, especially the ethylammonium tethering groups are flexible enough to interact with the disordered bridging iodine atoms in both positions. The aliphatic 4AMP cation, however, has a fixed configuration that may be responsible for the absence of such a disorder. Another difference is that in the (AE2T $)_{2} \mathrm{AgBiI}{ }_{8}$, the metal sites are also disordered, while in the present case, the $\mathrm{Ag}^{\mathrm{I}}$ and $\mathrm{Bi}^{\mathrm{III}}$ sites do show a long-range order. In the same paper $^{23}$, the authors proposed that the iodide $2 \mathrm{D}$ double perovskite is stabilized by the templating effect of the AE2T cation because of the edge-to-face intermolecular aromatic interaction. However, the fact that 2D iodide double perovskites can also form with aliphatic cations rules out that possibility.

The closest I $\cdots$ I distance is $3.98 \AA$ in the present study, because of the compact configuration of the cyclic cation, and the inorganic layers are stacking exactly on top of each other, which corresponds to the Dion-Jacobson 2D perovskite phase. There is a co-crystallized $\mathrm{H}_{2} \mathrm{O}$ molecule 
stabilized between two pyridinium $\mathrm{N}$ atoms by the hydrogen bonding (Figure 2c), ${ }^{39}$ with a N$\mathrm{H}^{\cdots} \mathrm{O}$ distance is $2.05 \AA$, but not between two primary $\mathrm{N}$ atoms, so the formula of the compound is $(4 \mathrm{AMP})_{2} \mathrm{AgBiI} \cdot 0.5 \mathrm{H}_{2} \mathrm{O}$. The $\mathrm{H}_{2} \mathrm{O}$ also exists in the related structures of $\left(\mathrm{C}_{6} \mathrm{H}_{14} \mathrm{~N}_{2}\right)_{2} \mathrm{AgBiI}{ }_{8} \cdot \mathrm{H}_{2} \mathrm{O}$ and $\left(\mathrm{C}_{6} \mathrm{H}_{14} \mathrm{~N}_{2}\right)_{2} \mathrm{CuBiI}_{8} \cdot 0.5 \mathrm{H}_{2} \mathrm{O}^{24}$.
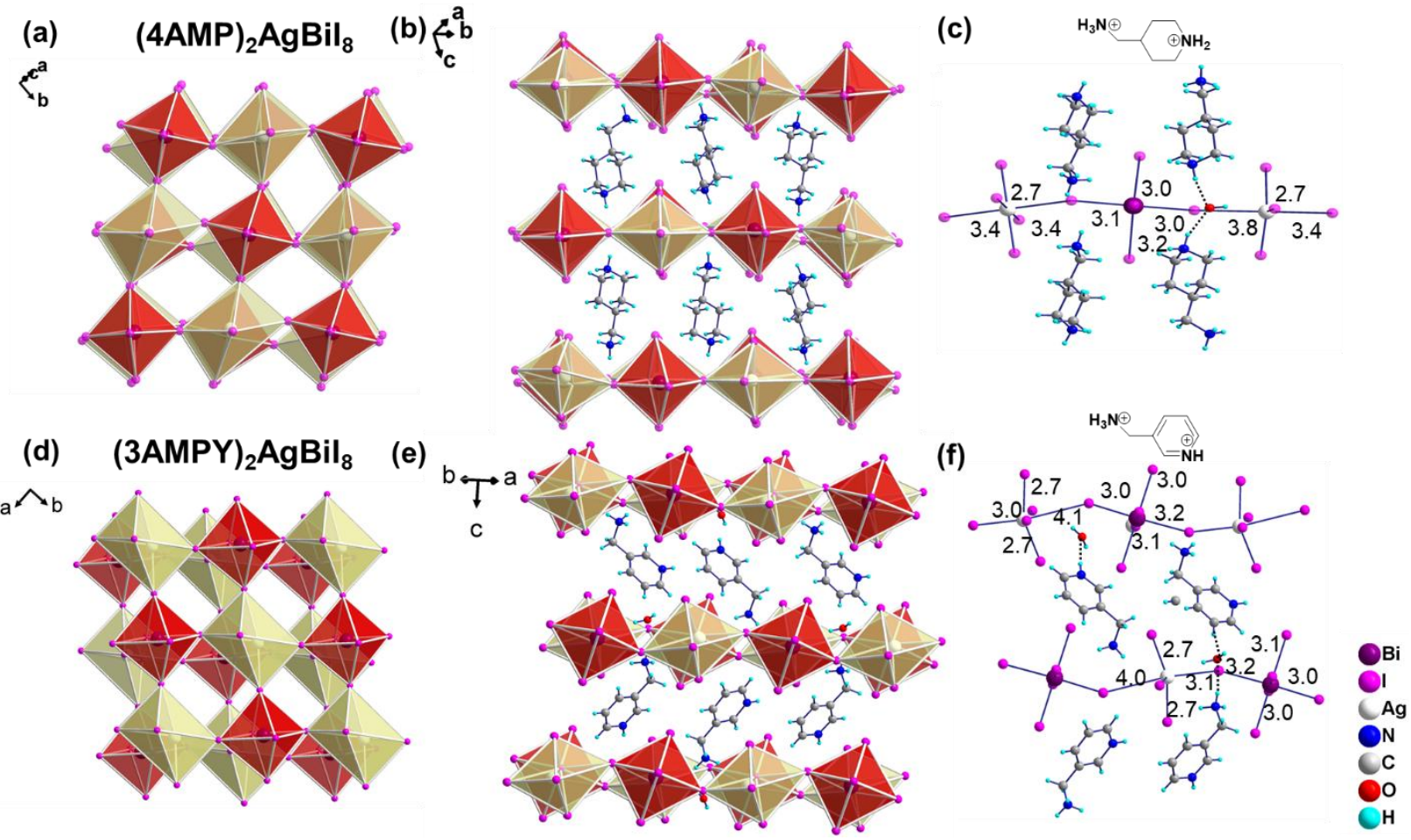

Figure 2. Crystal structures of $2 \mathrm{D}(4 \mathrm{AMP})_{2} \mathrm{AgBiI}_{8} \cdot 0.5 \mathrm{H}_{2} \mathrm{O}$ from (a) top view and (b) side view, and (c) showing the bond lengths and interaction with the cation. Crystal structures of $(3 \mathrm{AMPY})_{2} \mathrm{AgBiI}_{8} \cdot \mathrm{H}_{2} \mathrm{O}$ from (d) top view and (e) side view, and (f) showing the bond lengths and interaction with the cation. The light yellow octahedra are $\left(\mathrm{AgI}_{6}\right)^{5-}$ while the red ones are $\left(\mathrm{BiI}_{6}\right)^{3-}$.

Similar to $(4 \mathrm{AMP})_{2} \mathrm{AgBiI}{ }_{8} \cdot 0.5 \mathrm{H}_{2} \mathrm{O}$, the $(3 \mathrm{AMPY})_{2} \mathrm{AgBiI}{ }_{8} \cdot \mathrm{H}_{2} \mathrm{O}$ structure also exhibits ordered metal and iodine sites (Figure $2 \mathrm{~d}$ ), but adopts a lower symmetry space group of $P 1$ and unit cell of $\mathrm{a}=8.5577(2) \AA, \mathrm{b}=9.7387(2) \AA, \mathrm{c}=18.5585(4) \AA, \alpha=86.3032(12)^{\circ}, \beta=88.2019(11)^{\circ}$ and $\gamma=88.8251(10)^{\circ}$. The differences in coordination environment between the $\mathrm{Ag}^{\mathrm{I}}$ and $\mathrm{Bi}^{\mathrm{III}}$ sites are even more dramatic (Figure 2e). The distortion indexes for the $\mathrm{Ag}^{\mathrm{I}}$ and $\mathrm{Bi}^{\mathrm{III}}$ sites are 0.135 and 0.0154, respectively, which exhibit almost ten times difference. The longest $\mathrm{Ag} \cdots \mathrm{I}$ distance is $4.12 \AA$, which exceeds the sum of the van der Waals radii. In fact, the $\mathrm{Ag}^{\mathrm{I}}$ site is more inclined to adopt the seesaw coordination in this compound (Figure S2). 
The aromatic organic spacer 3AMPY is fully ordered and its configuration is determined explicitly by the electron densities of the $\mathrm{C}$ and $\mathrm{N}$ atoms (Figure 2f). Adjacent 3AMPY cations are parallel, instead of taking the face-to-edge interaction mode observed in the AE2T spacer cation. Interestingly, in $2 \mathrm{D}$ (3AMPY) $\mathrm{PbI}_{4},{ }^{7}$ the spacer cation does show the face-to-edge interaction. The inorganic layer exhibits a slight unit cell displacement of $(0.1,0.2)$ (Figure 2e), which is similar to that of the (3AMPY) $\mathrm{PbI}_{4}$. Unlike the aliphatic spacer (4AMP) whose ring is more bendable, the atoms of the aromatic spacer cation must be coplanar, thus inducing the inorganic layers stagger in order to accommodate the more rigid asymmetric cation. The closest $\mathrm{I} \cdots \mathrm{I}$ distance is $4.06 \AA$, which is slightly larger than in (4AMP) ${ }_{2} \mathrm{AgBiI} I_{8} \cdot 0.5 \mathrm{H}_{2} \mathrm{O}$ because of the offset of the inorganic layers. There are also co-crystallized $\mathrm{H}_{2} \mathrm{O}$ molecules stabilized in the structure, with a close $\mathrm{N}-\mathrm{H} \cdots \mathrm{O}$ distance of 1.9 and $2.3 \AA$ for the pyridine and primary $\mathrm{N}$ atoms, respectively, suggesting strong hydrogen bonds. Similar to $(4 \mathrm{AMP})_{2} \mathrm{AgBiI}_{8} \cdot 0.5 \mathrm{H}_{2} \mathrm{O}$, the adjacent four $\mathrm{Ag} \cdots \mathrm{Bi}$ distances are highly varied because of the heavily distorted structure, indicative of large strain.

To confirm the existence (and amount) of $\mathrm{H}_{2} \mathrm{O}$ molecules in the structures, we did thermogravimetric analysis (TGA) on the double perovskites (Figure S3). In the temperature range of $50-150{ }^{\circ} \mathrm{C}$ (Figure S3), the $(3 \mathrm{AMPY})_{2} \mathrm{AgBiI}{ }_{8} \cdot \mathrm{H}_{2} \mathrm{O}$ and $(4 \mathrm{AMP})_{2} \mathrm{AgBiI}_{8} \cdot 0.5 \mathrm{H}_{2} \mathrm{O}$ compounds exhibit $1.3 \%$ and $0.5 \%$ weight loss around $100{ }^{\circ} \mathrm{C}$, respectively, which corresponds to $0.5 \mathrm{H}_{2} \mathrm{O}$ and one $\mathrm{H}_{2} \mathrm{O}$ in the structure and matches with the formula from single-crystal characterization. Besides, we also observe that the $(4 \mathrm{AMP})_{2} \mathrm{AgBiI} \mathrm{I}_{8} \cdot 0.5 \mathrm{H}_{2} \mathrm{O}$ compound starts to decompose at a higher temperature $\left(31{ }^{\circ} \mathrm{C}\right)$ than $(3 \mathrm{AMPY})_{2} \mathrm{AgBiI}{ }_{8} \cdot \mathrm{H}_{2} \mathrm{O}\left(230{ }^{\circ} \mathrm{C}\right)$, probably because the (3AMPY) $)_{2} \mathrm{AgBiI}_{8} \cdot \mathrm{H}_{2} \mathrm{O}$ structure is more distorted.

Comparing the structures described to other reported 2D iodide double perovskites (Table S1), we find that they have several features in common. The $\mathrm{M}^{\mathrm{I}}$ octahedra are much more distorted than the $\mathrm{M}^{\mathrm{III}}$ ones, since the distortion index values of $\mathrm{M}^{\mathrm{I}}$ octahedra are one order of magnitude higher than those of $\mathrm{M}^{\mathrm{III}}$ ones. This is most obvious in the structures of $(3 \mathrm{AMPY})_{2} \mathrm{AgBiI}_{8} \cdot \mathrm{H}_{2} \mathrm{O}$, $\left(\mathrm{C}_{6} \mathrm{H}_{14} \mathrm{~N}_{2}\right)_{2} \mathrm{AgBiI}{ }_{8} \cdot \mathrm{H}_{2} \mathrm{O}$ and $\left(\mathrm{C}_{6} \mathrm{H}_{14} \mathrm{~N}_{2}\right)_{2} \mathrm{CuBiI}_{8} \cdot 0.5 \mathrm{H}_{2} \mathrm{O}$, where the $\mathrm{M}^{\mathrm{I}}$ sites are clearly off centered, so they are also called quasi-1D layered double perovskites. ${ }^{19}$ The $\mathrm{M}^{\mathrm{I}}$ sites are more inclined to form a seesaw coordination rather than the common octahedral coordination (Figure $\mathrm{S} 2$ ), as suggested by two ultra-long $\mathrm{M}^{\mathrm{I}}$-I bond distances, which are responsible for the large 
distortion index value. As mentioned above, the inability to form regular $\mathrm{M}^{\mathrm{I}} \mathrm{I}_{6}$ octahedral coordination is one of reasons why it is challenging to stabilize iodide double perovskites.

During the synthesis of the 2D iodide double perovskite phases, we also discovered several interesting 1D phases with both the aliphatic and aromatic cations, that provide important further insights into the interplay of structural and electronic structures of perovskite materials. The structures consist of $1 \mathrm{D}$ zigzag chains of $\mathrm{BiI}_{6}$ octahedra, which can be seen as a cis double wire structure. For each of the chain, the configuration of the octahedra is similar to that in $\langle 110\rangle$ oriented 2D perovskites without extending in two dimensions. For the structures of (3AMP)BiI 5 and (3AMPY)BiI 5 , the adjacent two chains are rotated (Figure 3a, c, viewing from b direction), with a dihedral angle of $69^{\circ}$ and $61^{\circ}$, respectively. Within each chain, the Bi-I-Bi angles are close to $180^{\circ}$. The average $\mathrm{Bi}-\mathrm{I}-\mathrm{Bi}$ angles for $(3 \mathrm{AMP}) \mathrm{BiI}_{5}$ and $(3 \mathrm{AMPY}) \mathrm{BiI}_{5}$ are $178.6^{\circ}$ and $179.7^{\circ}$ (Table 5), respectively. The closest $\mathrm{I}^{\cdots} \mathrm{I}$ distances are $4.11 \AA$ for $(3 \mathrm{AMP}) \mathrm{BiI}_{5}$ and (3AMPY)BiI 5 , respectively. Both are slightly smaller than the sum of the van del Waals radii (4.4 $\AA$ ), which suggests close interaction between the wires. The inorganic layers are separated by the organic cations and occupy well-defined positions with discrete conformations directed through weak hydrogen bonding interactions. A noteworthy difference between the 3AMP cation and the 3AMPY cation is that the former lies perpendicular to the $b$ direction while the latter is parallel

to
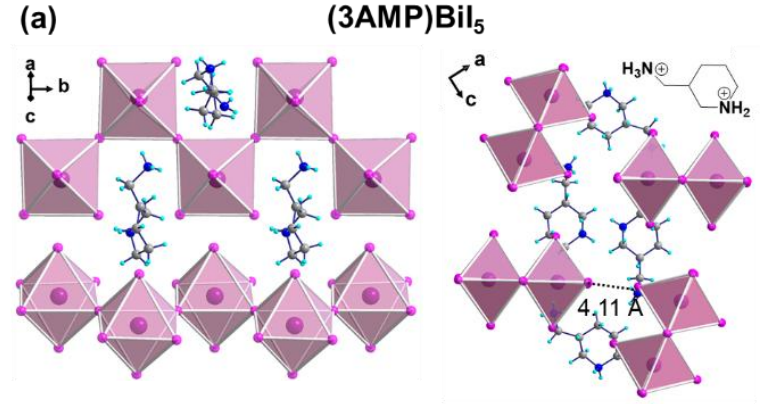

(c)

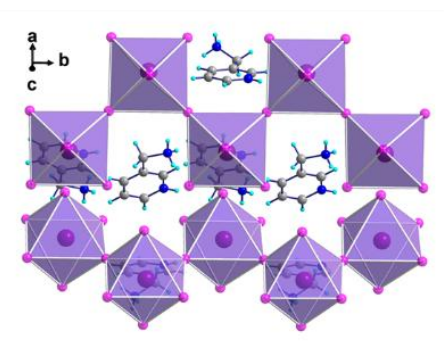

(3AMPY)Bil ${ }_{5}$

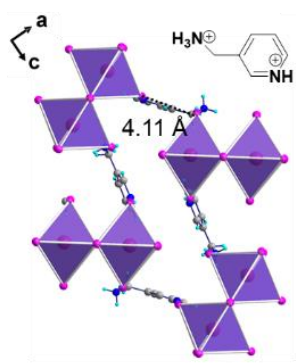

(b)

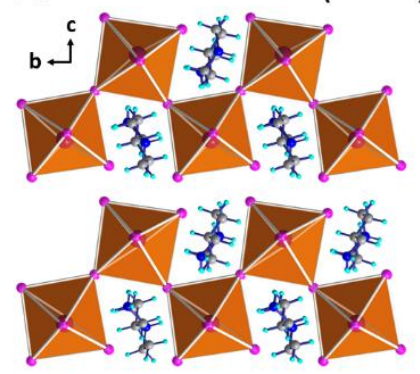

(d)

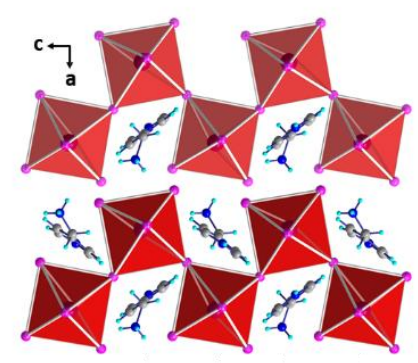

it.

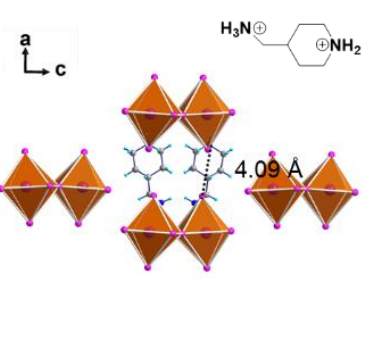

(4AMPY)Bil 5

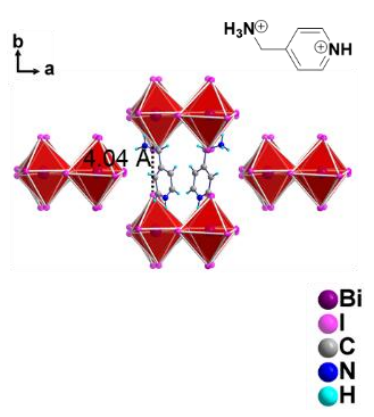


Figure 3. $1 \mathrm{D}$ chain structures of (a) $(3 \mathrm{AMP}) \mathrm{BiI}_{5}$, (b) $(4 \mathrm{AMP}) \mathrm{BiI}_{5}$, (c) $\left(3 \mathrm{AMPY} \mathrm{BiI}_{5}\right.$ and (d) (4AMPY)BiI ${ }_{5}$. The dash line indicates the shortest interchain distance.

For the structures of (4AMP)BiI $I_{5}$ and (4AMPY)BiI ${ }_{5}$, the adjacent two chains are parallel to each other (Figure 3b, d). The chain in each column is tilted, with average Bi-I-Bi angles of $160.9^{\circ}$ and $157.1^{\circ}$ for (4AMP)BiI $I_{5}$ and (4AMPY)BiI $I_{5}$ structures, respectively (Table 5). The wires in adjacent columns are offset by approximately half an octahedron. The closest I $\cdots$ I distances between chains in the same column, are $4.09 \AA$ and $4.04 \AA$ for (4AMP)BiI ${ }_{5}$ and (4AMPY)BiI 5 structures, respectively. This distance is much smaller than the $1 \mathrm{D} \mathrm{Bi}$ structures using longer diammonium cations. ${ }^{34,35}$ Both 4AMP and 4AMPY cations are parallel to the stacking direction. These results suggest that the symmetry (3AMP vs 4AMP) has a larger influence in the structure than the difference between the aliphatic (3AMP) and aromatic (3AMPY) cations, even though the atoms on the aliphatic ring can bend while those on the aromatic one must stay on the same plane.

Band structure calculations. We conducted density functional theory (DFT) calculations to obtain the electronic band structures using the experimental crystallographic data, and spin-orbit coupling (SOC) is considered for all the compounds. For each compound, we use the experimental structure to define the inorganic skeleton. However, in the case of 3AMPY and 4AMPY, we observe the presence of molecular states within the bandgap of the inorganic lattice (Figure S4). Despite our best efforts, we could not find any experimental evidence to support this point. The ordering might be a result of the well-known bandgap underestimation of DFT. However, the use of a hybrid functional (HSE06), even with high contributions of exact exchange (e.g., 43\%), did not modify the ordering of the molecular and inorganic conduction states (Figure S4). It remains unclear whether the position of the molecular states is an artifact of the DFT approach or not. In order to bypass this issue, organic cations are simply emulated by a background charge density. This tactic is known to have little impact on the band structure arising from the inorganic lattice, ${ }^{37}$ as we verify on $(4 \mathrm{AMP})_{2} \mathrm{AgBiI}{ }_{8} \cdot 0.5 \mathrm{H}_{2} \mathrm{O}$ (Figure S5). 

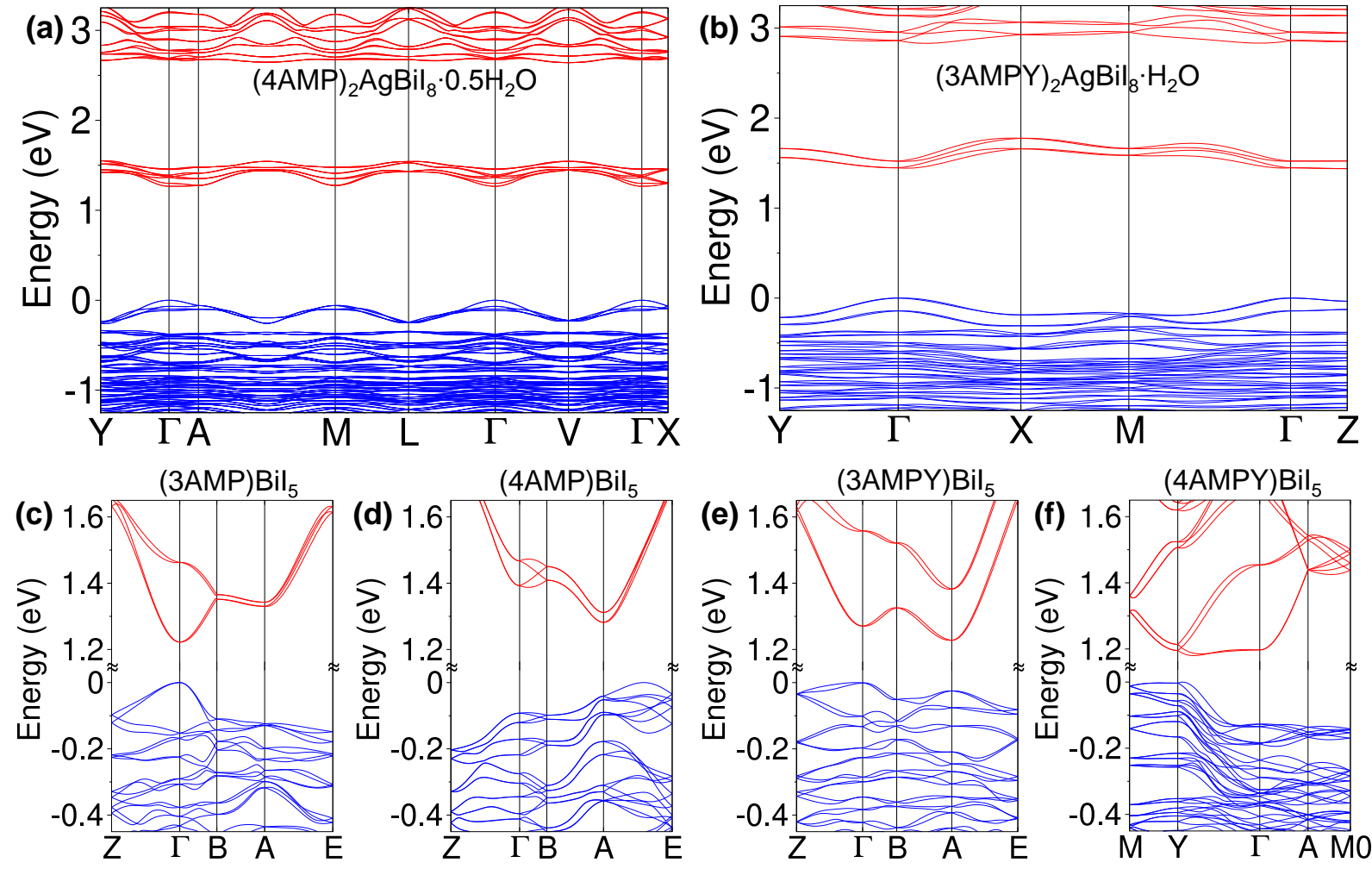

Figure 4. DFT calculations of band structures for (a) (4AMP) ${ }_{2} \mathrm{AgBiI}_{8} \cdot 0.5 \mathrm{H}_{2} \mathrm{O}$, (b) $(3 \mathrm{AMPY})_{2} \mathrm{AgBiI} \cdot \mathrm{H}_{2} \mathrm{O}$, (c) $\left(3 \mathrm{AMP}^{\mathrm{B}} \mathrm{BiI}_{5}\right.$, (d) $(4 \mathrm{AMP}) \mathrm{BiI}_{5}$, (e) $(3 \mathrm{AMPY}) \mathrm{BiI}_{5}$ and (f) $(4 \mathrm{AMPY}) \mathrm{BiI}_{5}$.

$(4 \mathrm{AMP})_{2} \mathrm{AgBiI}_{8} \cdot 0.5 \mathrm{H}_{2} \mathrm{O}$ compound exhibits a direct bandgap of $1.27 \mathrm{eV}$ at the $\Gamma$ point (Figure 4a). The (3AMPY $)_{2} \mathrm{AgBiI}_{8} \cdot \mathrm{H}_{2} \mathrm{O}$ compound also exhibits a nearly direct bandgap of $1.44 \mathrm{eV}$, which is slightly split due to the existence of the Rashba effect (Figure $4 \mathrm{~b}){ }^{40}$ However, because of the small bandwidth, the direct and indirect transitions are almost isoenergetic. In fact, the bands are relatively flat both at the valence and conduction band edges (compared to the regular perovskites), suggesting a low electronic dimension. The weak electronic coupling between the $\mathrm{Ag}$ and $\mathrm{Bi}$ octahedra indeed gives rise to a 0D-like electronic structure in the states close to the band gap. The inclusion of SOC in the calculations causes the splitting of bands characterized by the $\mathrm{Bi} 6 \mathrm{p}$ atomic states at the conduction band minimum (CBM), which is well-established for Bi-based halide perovskites. ${ }^{41}$ The split-off of conduction bands that shift down is attributed to the $\mathrm{Bi} 6 \mathrm{p}_{1 / 2}$ states, and the ones that shift up are assigned to $\mathrm{Bi} 6 \mathrm{p}_{3 / 2}$ states. The calculation results predict a wider bandgap for $(3 \mathrm{AMPY})_{2} \mathrm{AgBiI}_{8} \cdot \mathrm{H}_{2} \mathrm{O}$, which matches the experimental trend (vide infra) and attributed to the larger distortion of the octahedra. 
From the partial density of states (PDOS) plots (Figure S6), we can observe that the valence band maximum (VBM) is dominated by the I 5p states, as well as some Ag 4d states. The CBM is composed by the hybridization between $\mathrm{Bi} 6 \mathrm{p}$ and I $5 \mathrm{p}$ orbitals. The composition of the band edge states is similar to that of other reported $2 \mathrm{D}$ iodide double perovskites. ${ }^{23}$

The electronic band structures of the 1D compounds are magnified near the VBM and CBM, as shown in Figure 4c-f. The (3AMP)BiI 5 and (4AMPY)BiI 5 compounds are nearly direct bandgap semiconductors, with slight splitting due to the Rashba effect, and the calculated bandgaps are $1.22 \mathrm{eV}$ and $1.18 \mathrm{eV}$, respectively. The $\mathrm{VBM}$ of the (4AMP)BiI ${ }_{5}$ compound is between the $\mathrm{A}$ and E points of the Brillouin zone, while the CBM is at the A point, so it exhibits an indirect bandgap of $1.28 \mathrm{eV}$. The (3AMPY)BiI 5 exhibits an indirect transition from $\Gamma$ to $\mathrm{A}$, with a calculated bandgap of $1.23 \mathrm{eV}$. The calculation results match the experimental trend (vide infra) in the

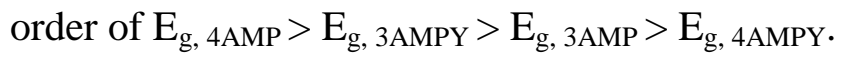

The valence bands for all 1D compounds are relatively flat but the conduction bands are more dispersive than the valence bands. The largest dispersions happen in the $\left(\mathrm{BiI}_{5}\right)^{2+}$ chain direction, which is not surprising since the octahedra are connected through corner-sharing in the real space. Interestingly, the bands are not totally flat in other directions. To explore the origin of those dispersions, we calculated the band structures of isolated wires, structures that retain contacts along a, and the complete structures (Figure S7). For (3AMPY)BiI $I_{5}$, the isolated $\left(\mathrm{BiI}_{5}\right)^{2+}$ chains exhibits dispersion only along the chain propagation direction, and the bands are flat in the other directions (Figure S8). However, when they are in close proximity to adjacent chains in the $a$ direction (via I...I van der Waals contacts), there is a clear dispersion in the conduction band between $\mathrm{B}$ and $\mathrm{A}$. This is an indication that lateral electronic coupling exists. In the complete structures, there is also a dispersion between $\Gamma$ and $\mathrm{B}$, which suggests strong interaction between the $\mathrm{BiI}_{5}$ chains. This is mainly because of the small size of the diammonium cations, which highlights the influence of the organic cations on the electronic structures. The other three compounds also exhibit similar trends (Figure S9). This agrees with the structural characterization which shows close I $\cdots$ I distances between chains for all four compounds.

\section{Optical properties}


The absorption spectra of the double and 1D perovskite structures are shown in Figure 5a. The bandgaps of the compounds range from 1.83 to $2.05 \mathrm{eV}$. The bandgap of $(3 \mathrm{AMPY})_{2} \mathrm{AgBiI}_{8} \cdot \mathrm{H}_{2} \mathrm{O}$ structure is higher than that of $(4 \mathrm{AMP})_{2} \mathrm{AgBiI}_{8} \cdot 0.5 \mathrm{H}_{2} \mathrm{O}$ because the structure is more distorted, as indicated by both the small Ag-Br-Bi angle and large distortion index (see above). This trend is also in agreement by the DFT calculations. The absorption edge of $(4 \mathrm{AMP})_{2} \mathrm{AgBiI} \cdot \mathrm{I}_{8} \cdot 0.5 \mathrm{H}_{2} \mathrm{O}$ is similar to the corresponding $1 \mathrm{D}$ compound $(4 \mathrm{AMP}) \mathrm{BiI}_{5}$, while the absorption edge of $(3 \mathrm{AMPY})_{2} \mathrm{AgBiI} \cdot \mathrm{H}_{2} \mathrm{O}$ is much higher in energy than (3AMPY)BiI ${ }_{5}$, which suggests the electronic dimension of the double perovskite structure is less than $1 \mathrm{D}$. The experimental results also confirm the theoretically predicted trend that $(3 \mathrm{AMPY})_{2} \mathrm{AgBiI}_{8} \cdot \mathrm{H}_{2} \mathrm{O}$ exhibits higher bandgap than $(4 \mathrm{AMP})_{2} \mathrm{AgBiI}_{8} \cdot 0.5 \mathrm{H}_{2} \mathrm{O}$. 

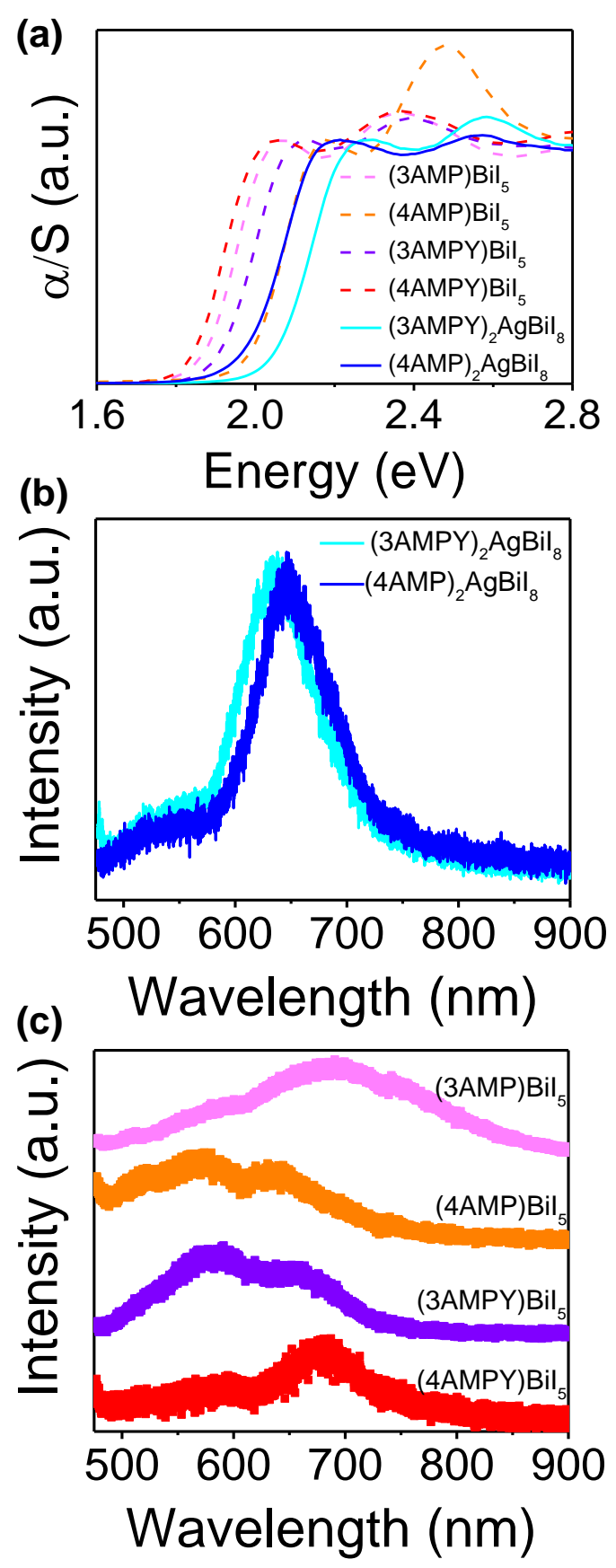

Figure 5. (a) Absorption spectra for all compounds reported here. (b) PL spectra for the double perovskite structures. (c) PL spectra for the 1D structures.

Previous work attributed the band edge absorption to the charge transfer between $\mathrm{Ag}$ and $\mathrm{Bi}^{20}$ Other authors suggest that this is unlikely because the Ag d orbitals mainly exist in VBM but have little contribution to the CBM, while the Bi p-orbitals mainly contribute to CBM but not much to the VBM, therefore "leaves little room for a nonzero metal-to-metal transition dipole 
matrix element". ${ }^{23}$ Our results suggests that since the I p-orbitals contribute to both the VBM and $\mathrm{CBM}$, the band edge absorption is more likely to originate from the transition from I 5p states in VBM to I 5p (and Bi 6p) states in CBM. We note that the combination of metal and halogen $p$ states in the CBM is not specific to the lead-free low-dimensional structures studied here, but a natural consequence of low symmetry-based electronic properties already described for leadbased perovskites. $^{42}$

The photoluminescence (PL) spectra of the double perovskite compounds are shown in Figure 5b. Their PL emission is very weak at room temperature, and we can observe a shoulder at around $530 \mathrm{~nm}$ and a main peak between 640 to $650 \mathrm{~nm}$. Those two peaks generally match with the two slopes from the absorption spectra. The PL intensity of the 1D compounds are weaker than those of the double perovskite phase (Figure 5c). They also exhibit two peaks (or one peak and a shoulder) corresponding to the two slopes in the absorption spectra. The peak positions of $(3 \mathrm{AMP}) \mathrm{BiI}_{5}$ and $(4 \mathrm{AMPY}) \mathrm{BiI}_{5}$ are at lower energy than those of the $(4 \mathrm{AMP}) \mathrm{BiI}_{5}$ and (3AMPY)BiI 5 are, which matches with the bandgap trend extracted from the absorption spectra. The weak observed emission is consistent with the DFT calculations which suggest that the transition is dipole-forbidden.

The Raman spectra of the compounds reported here are shown in Figure 6. They all exhibit distinct peaks below $200 \mathrm{~cm}^{-1}$. This is significantly different from the traditional 3D and 2D perovskites with $\mathrm{Pb}$, whose Raman spectra consist of broad central peaks around $0 \mathrm{~cm}^{-1}$ at room temperature, ${ }^{43}$ which suggests anharmonic and dynamically disordered lattice. ${ }^{44,} 45$ The Raman spectra of the 1D compounds consist of a main peak around $135 \mathrm{~cm}^{-1}$, as well as several overlapping peaks below $70 \mathrm{~cm}^{-1}$ with lower intensity. Based on the previous reports of similar Bi compounds, ${ }^{33}$ we assign the major peak to the Bi-I stretching modes. The low frequency peaks below $70 \mathrm{~cm}^{-1}$ can be assigned to various bending modes and Bi-I-Bi interactions. They exhibit weaker intensity than the stretching modes because the rotation and bending of the octahedra are restrained by the 1D chain. For the double perovskites, their Raman spectra look very similar to those of the $1 \mathrm{D}$ compounds with the major peak around $120 \mathrm{~cm}^{-1}$ and several overlapping peaks below $70 \mathrm{~cm}^{-1}$. So we tentatively assign the main peak to the stretching mode of the Bi-I stretching mode, while the $\left(\mathrm{AgI}_{6}\right)^{5-}$ modes remain almost silent. The bonding strength of $\mathrm{Bi}-\mathrm{I}$ is much stronger than the Ag-I in this case, due to the elongation of the Ag-I bonds. 
Besides, the $\left(\mathrm{BiI}_{6}\right)^{3-}$ octahedra are more uniform than the Ag ones, as suggested by the distortion index shown in Table S1. This is significantly different from the 3D double perovskite such as $\mathrm{Cs}_{2} \mathrm{AgBiBr}_{6}$, where the $\mathrm{Ag}$ modes dominate because the $\mathrm{Ag}-\mathrm{Br}$ bond strength is stronger and the $\left(\mathrm{AgBr}_{6}\right)^{5-}$ octahedra are more uniform than the $\left(\mathrm{AgI}_{6}\right)^{5-}$ ones. ${ }^{46}$ However, the main peak does shift to lower frequency and broadens, which is subject to further exploration. Overall, these results suggest a more rigid lattice with more distinct phonon modes, compared to the corresponding 2D Pb-based perovskites which is consistent with the smaller and more isotropic thermal displacement parameters of the iodine atoms in their structures than in $2 \mathrm{D} \mathrm{Pb}$ perovskites (Table S2- S13). ${ }^{43}$

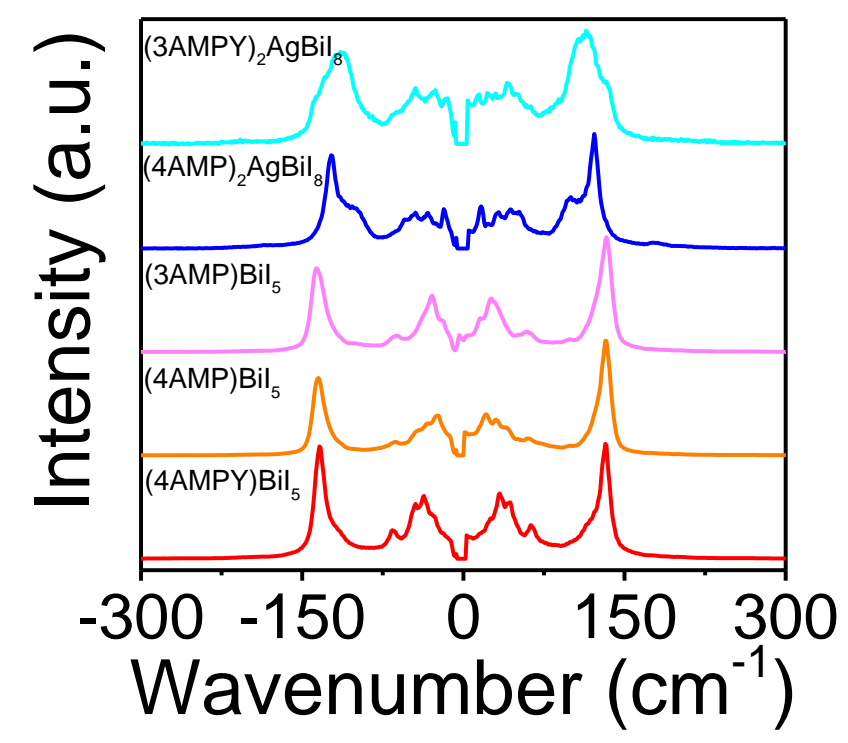

Figure 6. Room temperature Raman spectra of compounds reported here.

\section{Conclusions}

By comparing Bi/Ag-based 2D iodide double perovskites and 1D Bi-based chain compounds, we can see that the structural and electronic dimensions are not necessarily the same. The double perovskites are structurally connected in $2 \mathrm{D}$, but their electronic structures are more like $0 \mathrm{D}$ because of the electronic decoupling of the Ag and Bi octahedra. The electronic dimension of the 1D compounds is the same as their structural dimension. They also exhibit appreciable dispersion in the interchain direction thanks to the close distances between the wires, which 
suggests electronic coupling between the chains. The double perovskite compounds exhibit similar or higher bandgaps than the 1D compounds with the same cation, which confirms their lower electronic dimensions. In a way it is useful to view the role of $\mathrm{Ag}$ atoms in these compounds as nodes that act to isolate the $\left(\mathrm{BiI}_{6}\right)^{3-}$ octahedra creating a $0 \mathrm{D}$ situation. In contrast, in the $1 \mathrm{D}$ structures the $\left(\mathrm{BiI}_{6}\right)^{3-}$ octahedra are connected via corner-sharing at least along one direction. These seemingly counterintuitive results suggest that it is equally important to consider the details of the electronic structure as carefully as the crystal structure when interpreting experimental observations and in determining the potential application of the materials.

\section{ASSOCIATED CONTENT}

\section{Supporting Information}

More experimental details for powder X-ray diffraction, absorption spectroscopy, crystallographic details and DFT calculations.

X-ray crystallographic data of $(4 \mathrm{AMP})_{2} \mathrm{AgBiI}_{8} \cdot 0.5 \mathrm{H}_{2} \mathrm{O}$.

X-ray crystallographic data of $(3 \mathrm{AMPY})_{2} \mathrm{AgBiI}_{8} \cdot \mathrm{H}_{2} \mathrm{O}$.

X-ray crystallographic data of (3AMP)BiI 5 .

X-ray crystallographic data of (4AMP)BiI .

X-ray crystallographic data of (3AMPY)BiI 5 .

X-ray crystallographic data of (4AMPY)BiI 5.

\section{Author information}

\section{Corresponding Author}

*m-kanatzidis@northwestern.edu

\section{Notes}

The authors declare no competing financial interest.

\section{Acknowledgements}


At Northwestern University this work is mainly supported by the Department of Energy, Office of Science, Basic Energy Sciences, under Grant No. SC0012541 (synthesis, structure, and physical property characterization). For DFT calculations, the work was granted access to the HPC resources of TGCC/CINES/IDRIS under the allocation 2019-A0080911434, 2020A0080911434 and 2020-A0090907682 made by GENCI. M. K. acknowledges support from Region Bretagne through Boost'ERC LaHPerOS project. J.E acknowledges the financial support from the Institut Universitaire de France. This work made use of the SPID (confocal microscopy) facilities of Northwestern University's NUANCE Center, which has received support from the Soft and Hybrid Nanotechnology Experimental Resource (NSF ECCS1542205), the Materials Research Science and Engineering Centers (NSF DMR-1720139), the International Institute for Nanotechnology (IIN), the Keck Foundation, and the State of Illinois through the IIN. Work at Yale is supported by the Yale University Lab Setup Fund. 


\section{References}

1. Saparov, B.; Mitzi, D. B., Organic-Inorganic Perovskites: Structural Versatility for Functional Materials Design. Chem. Rev. 2016, 116 (7), 4558-4596.

2. Mao, L.; Stoumpos, C. C.; Kanatzidis, M. G., Two-Dimensional Hybrid Halide Perovskites: Principles and Promises. J. Am. Chem. Soc. 2019, 141 (3), 1171-1190.

3. Li, X.; Hoffman, J. M.; Kanatzidis, M. G., The 2D Halide Perovskite Rulebook: How the Spacer Influences Everything from the Structure to Optoelectronic Device Efficiency. Chem. Rev. 2021, 121 (4), 2230-2291.

4. Tsai, H.; Nie, W.; Blancon, J.-C.; Stoumpos, C. C.; Asadpour, R.; Harutyunyan, B.; Neukirch, A. J.; Verduzco, R.; Crochet, J. J.; Tretiak, S.; Pedesseau, L.; Even, J.; Alam, M. A.; Gupta, G.; Lou, J.; Ajayan, P. M.; Bedzyk, M. J.; Kanatzidis, M. G.; Mohite, A. D., High-efficiency two-dimensional Ruddlesden-Popper perovskite solar cells. Nature 2016, 536 (7616), 312-316.

5. Smith, I. C.; Hoke, E. T.; Solis-Ibarra, D.; McGehee, M. D.; Karunadasa, H. I., A Layered Hybrid Perovskite Solar-Cell Absorber with Enhanced Moisture Stability. Angew. Chem., Int. Ed. 2014, 53 (42), 11232-11235.

6. Cao, D. H.; Stoumpos, C. C.; Farha, O. K.; Hupp, J. T.; Kanatzidis, M. G., 2D Homologous Perovskites as Light-Absorbing Materials for Solar Cell Applications. J. Am. Chem. Soc. 2015, 137 (24), 7843-7850.

7. Li, X.; Ke, W.; Traoré, B.; Guo, P.; Hadar, I.; Kepenekian, M.; Even, J.; Katan, C.; Stoumpos, C. C.; Schaller, R. D.; Kanatzidis, M. G., Two-Dimensional Dion-Jacobson Hybrid Lead lodide Perovskites with Aromatic Diammonium Cations. J. Am. Chem. Soc. 2019, 141 (32), 12880-12890.

8. Li, X.; Hoffman, J.; Ke, W.; Chen, M.; Tsai, H.; Nie, W.; Mohite, A. D.; Kepenekian, M.; Katan, C.; Even, J.; Wasielewski, M. R.; Stoumpos, C. C.; Kanatzidis, M. G., Two-Dimensional Halide Perovskites Incorporating Straight Chain Symmetric Diammonium lons, $\left(\mathrm{NH}_{3} \mathrm{C}_{\mathrm{m}} \mathrm{H}_{2 m} \mathrm{NH}_{3}\right)\left(\mathrm{CH}_{3} \mathrm{NH}_{3}\right)_{\mathrm{n}-1} \mathrm{~Pb}_{\mathrm{n}} \mathrm{I}_{3 \mathrm{n}+1}(\mathrm{~m}=4-9$; $\mathrm{n}=1-4)$. J. Am. Chem. Soc. 2018, 140 (38), 12226-12238.

9. Yuan, M.; Quan, L. N.; Comin, R.; Walters, G.; Sabatini, R.; Voznyy, O.; Hoogland, S.; Zhao, Y.; Beauregard, E. M.; Kanjanaboos, P.; Lu, Z.; Kim, D. H.; Sargent, E. H., Perovskite energy funnels for efficient light-emitting diodes. Nat. Nanotechnol. 2016, 11 (10), 872-877.

10. Liu, Y.; Zhang, Y.; Yang, Z.; Ye, H.; Feng, J.; Xu, Z.; Zhang, X.; Munir, R.; Liu, J.; Zuo, P.; Li, Q.; Hu, M.; Meng, L.; Wang, K.; Smilgies, D.-M.; Zhao, G.; Xu, H.; Yang, Z.; Amassian, A.; Li, J.; Zhao, K.; Liu, S., Multi-inch single-crystalline perovskite membrane for high-detectivity flexible photosensors. Nat. Commun. 2018, 9 (1), 5302.

11. Shi, E.; Yuan, B.; Shiring, S. B.; Gao, Y.; Akriti; Guo, Y.; Su, C.; Lai, M.; Yang, P.; Kong, J.; Savoie, B. M.; Yu, Y.; Dou, L., Two-dimensional halide perovskite lateral epitaxial heterostructures. Nature 2020, 580 (7805), 614-620.

12. Katan, C.; Mercier, N.; Even, J., Quantum and Dielectric Confinement Effects in LowerDimensional Hybrid Perovskite Semiconductors. Chem. Rev. 2019, 119 (5), 3140-3192.

13. Fabini, D. H.; Seshadri, R.; Kanatzidis, M. G., The underappreciated lone pair in halide perovskites underpins their unusual properties. MRS Bulletin 2020, 45 (6), 467-477.

14. Slavney, A. H.; Hu, T.; Lindenberg, A. M.; Karunadasa, H. I., A Bismuth-Halide Double Perovskite with Long Carrier Recombination Lifetime for Photovoltaic Applications. J. Am. Chem. Soc. 2016, 138 (7), 2138-2141.

15. McClure, E. T.; Ball, M. R.; Windl, W.; Woodward, P. M., $\mathrm{Cs}_{2} \mathrm{AgBiX}_{6}(\mathrm{X}=\mathrm{Br}, \mathrm{Cl})$ : New Visible Light Absorbing, Lead-Free Halide Perovskite Semiconductors. Chem. Mater. 2016, 28 (5), 1348-1354. 
16. Wolf, N. R.; Connor, B. A.; Slavney, A. H.; Karunadasa, H., Doubling the Stakes: The Promise of Halide Double Perovskites. Angew. Chem., Int. Ed. 2021, n/a (n/a).

17. Li, C.; Lu, X.; Ding, W.; Feng, L.; Gao, Y.; Guo, Z., Formability of ABX3 (X= F, Cl, Br, I) halide perovskites. Acta Crystallographica Section B 2008, 64 (6), 702-707.

18. Vishnoi, P.; Seshadri, R.; Cheetham, A. K., Why are Double Perovskite lodides so Rare? J. Phys. Chem. C 2021, 125 (21), 11756-11764.

19. Vargas, B.; Rodríguez-López, G.; Solis-Ibarra, D., The Emergence of Halide Layered Double Perovskites. ACS Energy Lett. 2020, 5 (11), 3591-3608.

20. Connor, B. A.; Leppert, L.; Smith, M. D.; Neaton, J. B.; Karunadasa, H. I., Layered Halide Double Perovskites: Dimensional Reduction of Cs2AgBiBr6. J. Am. Chem. Soc. 2018, 140 (15), 5235-5240.

21. Mao, L.; Teicher, S. M. L.; Stoumpos, C. C.; Kennard, R. M.; DeCrescent, R. A.; Wu, G.; Schuller, J. A.; Chabinyc, M. L.; Cheetham, A. K.; Seshadri, R., Chemical and Structural Diversity of Hybrid Layered Double Perovskite Halides. J. Am. Chem. Soc. 2019, 141 (48), 19099-19109.

22. Evans, H. A.; Mao, L.; Seshadri, R.; Cheetham, A. K., Layered Double Perovskites. Annu. Rev. Mater. Res. 2021, 51 (1).

23. Jana, M. K.; Janke, S. M.; Dirkes, D. J.; Dovletgeldi, S.; Liu, C.; Qin, X.; Gundogdu, K.; You, W.; Blum, V.; Mitzi, D. B., A Direct-Bandgap 2D Silver-Bismuth lodide Double Perovskite: The StructureDirecting Influence of an Oligothiophene Spacer Cation. J. Am. Chem. Soc. 2019, 141 (19), 7955-7964.

24. Bi, L.-Y.; Hu, Y.-Q.; Li, M.-Q.; Hu, T.; Zhang, H.-L.; Yin, X.; Que, W.; Lassoued, M. S.; Zheng, Y.Z., Two-dimensional lead-free iodide-based hybrid double perovskites: crystal growth, thin-film preparation and photocurrent responses. J. Mater. Chem. A 2019, 7 (34), 19662-19667.

25. Bi, L.-Y.; Hu, T.-L.; Li, M.-Q.; Ling, B.-K.; Lassoued, M. S.; Hu, Y.-Q.; Wu, Z.; Zhou, G.; Zheng, Y.Z., Template effects in $\mathrm{Cu}(\mathrm{i})-\mathrm{Bi}$ (iii) iodide double perovskites: a study of crystal structure, film orientation, band gap and photocurrent response. J. Mater. Chem. A 2020, 8 (15), 7288-7296.

26. Lassoued, M. S.; Bi, L.-Y.; Wu, Z.; Zhou, G.; Zheng, Y.-Z., Piperidine-induced Switching of the direct band gaps of $\mathrm{Ag}(\mathrm{i}) / \mathrm{Bi}(\mathrm{iii})$ bimetallic iodide double perovskites. J. Mater. Chem. C 2020, 8 (16), 5349-5354.

27. Yao, Y.; Kou, B.; Peng, Y.; Wu, Z.; Li, L.; Wang, S.; Zhang, X.; Liu, X.; Luo, J., $\left(\mathrm{C}_{3} \mathrm{H}_{9} \mathrm{NI}\right)_{4} \mathrm{AgBil}_{8}$ : a direct-bandgap layered double perovskite based on a short-chain spacer cation for light absorption. Chem. Commun. 2020, 56 (21), 3206-3209.

28. Wang, C.-F.; Li, H.; Li, M.-G.; Cui, Y.; Son, X.; Wang, Q.-W.; Jiang, J.-Y.; Hua, M.-M.; Xu, Q.; Zhao, K.; Ye, H.-Y.; Zhang, Y., Centimeter-Sized Single Crystals of Two-Dimensional Hybrid lodide Double Perovskite (4,4-Difluoropiperidinium)4AgBil8 for High-Temperature Ferroelectricity and Efficient X-Ray Detection. Adv. Funct. Mater. 2021, 31 (13), 2009457.

29. Li, D.; liu, x.; wu, w.; peng, y.; zhao, s.; li, l.; hong, m.; Luo, J., Chiral lead-free hybrid perovskites for self-powered circularly polarized light detection. Angew. Chem., Int. Ed. 2020, 60 (15), 8415-8418.

30. Xiao, Z.; Meng, W.; Wang, J.; Mitzi, D. B.; Yan, Y., Searching for promising new perovskitebased photovoltaic absorbers: the importance of electronic dimensionality. Mater. Horiz. 2017, 4 (2), 206-216.

31. Slavney, A. H.; Leppert, L.; Saldivar Valdes, A.; Bartesaghi, D.; Savenije, T. J.; Neaton, J. B.; Karunadasa, H. I., Small-Band-Gap Halide Double Perovskites. Angew. Chem. 2018, 130 (39), 1294712952.

32. McCall, K. M.; Friedrich, D.; Chica, D. G.; Cai, W.; Stoumpos, C. C.; Alexander, G. C. B.; Deemyad, S.; Wessels, B. W.; Kanatzidis, M. G., Perovskites with a Twist: Strong In1+ Off-centering in the Mixed-Valent $\mathrm{C} \operatorname{In} \mathrm{X}_{3}(\mathrm{X}=\mathrm{Cl}, \mathrm{Br})$. Chem. Mater. 2019. 
33. McCall, K. M.; Stoumpos, C. C.; Kostina, S. S.; Kanatzidis, M. G.; Wessels, B. W., Strong Electron-Phonon Coupling and Self-Trapped Excitons in the Defect Halide Perovskites $A_{3} M_{2} l_{9}(A=C s, R b$; $\mathrm{M}=\mathrm{Bi}, \mathrm{Sb})$. Chem. Mater. 2017.

34. Mitzi, D. B.; Brock, P., Structure and Optical Properties of Several Organic-Inorganic Hybrids Containing Corner-Sharing Chains of Bismuth lodide Octahedra. Inorg. Chem. 2001, 40 (9), 2096-2104.

35. Mousdis, G. A.; Papavassiliou, G. C.; Terzis, A.; Raptopoulou, C. P., Notizen: Preparation, Structures and Optical Properties of $\left[\mathrm{H}_{3} \mathrm{~N}\left(\mathrm{CH}_{2}\right)_{6} \mathrm{NH}_{3}\right] \mathrm{BiX} \mathrm{X}_{5}(\mathrm{X}=\mathrm{I}, \mathrm{Cl})$ and $\left[\mathrm{H}_{3} \mathrm{~N}\left(\mathrm{CH}_{2}\right)_{6} \mathrm{NH}_{3}\right] \mathrm{SbX} \mathrm{X}_{5}(\mathrm{X}=\mathrm{I}, \mathrm{Br}) . Z$. Naturforsch. B 1998, 53 (8), 927-932.

36. Lehner, A. J.; Fabini, D. H.; Evans, H. A.; Hébert, C.-A.; Smock, S. R.; Hu, J.; Wang, H.; Zwanziger, J. W.; Chabinyc, M. L.; Seshadri, R., Crystal and Electronic Structures of Complex Bismuth lodides $\mathrm{A}_{3} \mathrm{Bi}_{2} \mathrm{l}_{9}(\mathrm{~A}=\mathrm{K}, \mathrm{Rb}, \mathrm{Cs})$ Related to Perovskite: Aiding the Rational Design of Photovoltaics. Chem. Mater. 2015, 27 (20), 7137-7148.

37. Li, X.; He, Y.; Kepenekian, M.; Guo, P.; Ke, W.; Even, J.; Katan, C.; Stoumpos, C. C.; Schaller, R. D.; Kanatzidis, M. G., Three-dimensional Lead lodide Perovskitoid Hybrids with High X-ray Photoresponse. J. Am. Chem. Soc. 2020, 142 (14), 6625-6637.

38. Mercier, N.; Louvain, N.; Bi, W., Structural diversity and retro-crystal engineering analysis of iodometalate hybrids. CrystEngComm 2009, 11 (5), 720-734.

39. Steiner, T., The Hydrogen Bond in the Solid State. Angew. Chem., Int. Ed. 2002, 41 (1), 48-76.

40. Kepenekian, M.; Robles, R.; Katan, C.; Sapori, D.; Pedesseau, L.; Even, J., Rashba and Dresselhaus Effects in Hybrid Organic-Inorganic Perovskites: From Basics to Devices. ACS Nano 2015, 9 (12), 11557-11567.

41. Filip, M. R.; Hillman, S.; Haghighirad, A. A.; Snaith, H. J.; Giustino, F., Band Gaps of the LeadFree Halide Double Perovskites $\mathrm{Cs}_{2} \mathrm{BiAgCl}_{6}$ and $\mathrm{Cs}_{2} \mathrm{BiAgBr}_{6}$ from Theory and Experiment. J. Phys. Chem. Lett. 2016, 7 (13), 2579-2585.

42. Blancon, J.-C.; Even, J.; Stoumpos, C. C.; Kanatzidis, M. G.; Mohite, A. D., Semiconductor physics of organic-inorganic 2D halide perovskites. Nature Nanotechnology 2020, 15 (12), 969-985.

43. Li, X.; Fu, Y.; Pedesseau, L.; Guo, P.; Cuthriell, S.; Hadar, I.; Even, J.; Katan, C.; Stoumpos, C. C.; Schaller, R. D.; Harel, E.; Kanatzidis, M. G., Negative Pressure Engineering with Large Cage Cations in 2D Halide Perovskites Causes Lattice Softening. J. Am. Chem. Soc. 2020, 142 (26), 11486-11496.

44. Quarti, C.; Grancini, G.; Mosconi, E.; Bruno, P.; Ball, J. M.; Lee, M. M.; Snaith, H. J.; Petrozza, A.; De Angelis, F., The Raman Spectrum of the $\mathrm{CH}_{3} \mathrm{NH}_{3} \mathrm{Pbl}_{3}$ Hybrid Perovskite: Interplay of Theory and Experiment. J. Phys. Chem. Lett. 2014, 5 (2), 279-284.

45. Yaffe, O.; Guo, Y.; Tan, L. Z.; Egger, D. A.; Hull, T.; Stoumpos, C. C.; Zheng, F.; Heinz, T. F.; Kronik, L.; Kanatzidis, M. G.; Owen, J. S.; Rappe, A. M.; Pimenta, M. A.; Brus, L. E., Local Polar Fluctuations in Lead Halide Perovskite Crystals. Phys. Rev. Lett. 2017, 118 (13), 136001.

46. Steele, J. A.; Puech, P.; Keshavarz, M.; Yang, R.; Banerjee, S.; Debroye, E.; Kim, C. W.; Yuan, H.; Heo, N. H.; Vanacken, J.; Walsh, A.; Hofkens, J.; Roeffaers, M. B. J., Giant Electron-Phonon Coupling and Deep Conduction Band Resonance in Metal Halide Double Perovskite. ACS Nano 2018, 12 (8), 8081-8090. 
Table 1. Crystal and Refinement Data for the Double Perovskites.

\begin{tabular}{|c|c|c|}
\hline & $(3 \mathrm{AMPY})_{2} \mathrm{AgBiI}_{8} \cdot \mathrm{H}_{2} \mathrm{O}$ & $(4 \mathrm{AMP})_{2} \mathrm{AgBiI}_{8} \cdot 0.5 \mathrm{H}_{2} \mathrm{O}$ \\
\hline Crystal system & triclinic & monoclinic \\
\hline Space group & $P 1$ & $C 2 / c$ \\
\hline Unit cell dimensions & $\begin{array}{l}\mathrm{a}=8.5577(2) \AA \\
\mathrm{b}=9.7387(2) \AA \\
\mathrm{c}=18.5585(4) \AA \\
\alpha=86.3032(12)^{\circ} \\
\beta=88.2019(11)^{\circ} \\
\gamma=88.8251(10)^{\circ}\end{array}$ & $\begin{array}{l}a=34.988(7) \AA \\
b=8.4789(17) \AA \\
c=22.226(4) \AA \\
\beta=96.92(3)^{\circ}\end{array}$ \\
\hline Volume & $1542.44(6) \AA^{3}$ & $6545(2) \AA^{3}$ \\
\hline $\mathrm{Z}$ & 2 & 16 \\
\hline Index ranges & $\begin{array}{l}-12<=\mathrm{h}<=12,-13<=\mathrm{k}<=13, \\
-26<=\mathrm{l}<=26\end{array}$ & $\begin{array}{l}-47<=\mathrm{h}<=47,-11<=\mathrm{k}<=11, \\
-29<=\mathrm{l}<=30\end{array}$ \\
\hline Independent reflections & $17621\left[\mathrm{R}_{\mathrm{int}}=0.0312\right]$ & $8718\left[\mathrm{R}_{\mathrm{int}}=0.0461\right]$ \\
\hline Completeness to $\theta=25^{\circ}$ & $100 \%$ & $99.3 \%$ \\
\hline Data / restraints / parameters & $17621 / 32$ / 299 & $8718 / 16 / 164$ \\
\hline Goodness-of-fit & 1.082 & 0.891 \\
\hline Final $R$ indices $[\mathrm{I}>2 \sigma(\mathrm{I})]$ & $\mathrm{R}_{\mathrm{obs}}=0.0406, \mathrm{wR}_{\mathrm{obs}}=0.1163$ & $\mathrm{R}_{\mathrm{obs}}=0.0316, \mathrm{wR}_{\mathrm{obs}}=0.0532$ \\
\hline $\mathrm{R}$ indices [all data] & $\mathrm{R}_{\mathrm{all}}=0.0518, \mathrm{wR}_{\mathrm{all}}=0.1260$ & $\mathrm{R}_{\mathrm{all}}=0.0724, \mathrm{w} \mathrm{R}_{\mathrm{all}}=0.0605$ \\
\hline Largest diff. peak and hole & 3.469 and $-3.055 \mathrm{e} \cdot \AA^{-3}$ & 1.154 and $-1.287 \mathrm{e} \cdot \AA^{-3}$ \\
\hline
\end{tabular}


Table 2. Crystal and Refinement Data for the 1D Perovskites.

\begin{tabular}{|c|c|c|c|c|}
\hline & $(3 \mathrm{AMP}) \mathrm{BiI}_{5}$ & $(4 \mathrm{AMP}) \mathrm{BiI}_{5}$ & $(3 \mathrm{AMPY}) \mathrm{BiI}_{5}$ & (4AMPY)BiI ${ }_{5}$ \\
\hline Crystal system & monoclinic & monoclinic & monoclinic & monoclinic \\
\hline Space group & $P 2_{1}$ & $P 2_{1}$ & $P 2_{1}$ & $C c$ \\
\hline $\begin{array}{l}\text { Unit cell } \\
\text { dimensions }\end{array}$ & $\begin{array}{l}\mathrm{a}=12.740(3) \AA \\
\mathrm{b}=8.9285(18) \AA \\
\mathrm{c}=16.404(3) \AA \\
\beta=90.09(3)^{\circ}\end{array}$ & $\begin{array}{l}\mathrm{a}=10.240(2) \AA \\
\mathrm{b}=8.4579(17) \AA \\
\mathrm{c}=21.347(4) \AA \\
\beta=90.14(3)^{\circ}\end{array}$ & $\begin{array}{l}\mathrm{a}=10.930(2) \AA \\
\mathrm{b}=9.0996(18) \AA \\
\mathrm{c}=17.651(4) \AA \\
\beta=90.29(3)^{\circ}\end{array}$ & $\begin{array}{l}\mathrm{a}=19.550(4) \AA \\
\mathrm{b}=10.108(2) \AA \\
\mathrm{c}=17.163(3) \AA \\
\beta=90.00(3)^{\circ}\end{array}$ \\
\hline Volume & $1866.1(7) \AA^{3}$ & $1848.9(6) \AA^{3}$ & $1755.5(6) \AA^{3}$ & $3391.6(12) \AA^{3}$ \\
\hline Z & 4 & 4 & 4 & 8 \\
\hline Index ranges & $\begin{array}{l}-17<=\mathrm{h}<=15 \\
-12<=\mathrm{k}<=12 \\
-22<=\mathrm{l}=22\end{array}$ & $\begin{array}{l}-12<=\mathrm{h}<=14 \\
-11<=\mathrm{k}<=11 \\
-29<=\mathrm{l}<=29\end{array}$ & $\begin{array}{l}-13<=\mathrm{h}<=14 \\
-12<=\mathrm{k}<=12 \\
-24<=\mathrm{l}<=24\end{array}$ & $\begin{array}{l}-24<=\mathrm{h}<=26 \\
-13<=\mathrm{k}<=13 \\
-23<=\mathrm{l}<=23\end{array}$ \\
\hline $\begin{array}{l}\text { Independent } \\
\text { reflections }\end{array}$ & $\begin{array}{l}6742\left[\mathrm{R}_{\text {int }}=\right. \\
0.0722]\end{array}$ & $\begin{array}{l}9860\left[\mathrm{R}_{\mathrm{int}}=\right. \\
0.0385]\end{array}$ & $\begin{array}{l}6330\left[\mathrm{R}_{\text {int }}=\right. \\
0.1478]\end{array}$ & $\begin{array}{l}8265\left[\mathrm{R}_{\mathrm{int}}=\right. \\
0.0650]\end{array}$ \\
\hline $\begin{array}{l}\text { Completeness to } \theta \\
=25^{\circ}\end{array}$ & $99 \%$ & $99.4 \%$ & $99 \%$ & $98.5 \%$ \\
\hline $\begin{array}{l}\text { Data / restraints / } \\
\text { parameters }\end{array}$ & $6742 / 30 / 160$ & 9860 / 17 / 162 & $6330 / 34 / 160$ & 8265 / 4 / 175 \\
\hline Goodness-of-fit & 2.55 & 1.066 & 4.56 & 1.010 \\
\hline $\begin{array}{l}\text { Final } R \text { indices } \\
{[I>2 \sigma(I)]}\end{array}$ & $\begin{array}{l}\mathrm{R}_{\mathrm{obs}}=0.0644 \\
\mathrm{wR}_{\mathrm{obs}}=0.0877\end{array}$ & $\begin{array}{l}\mathrm{R}_{\mathrm{obs}}=0.0331 \\
\mathrm{wR}_{\mathrm{obs}}=0.0752\end{array}$ & $\begin{array}{l}\mathrm{R}_{\mathrm{obs}}=0.0929 \\
\mathrm{wR}_{\mathrm{obs}}=0.1013\end{array}$ & $\begin{array}{l}\mathrm{R}_{\mathrm{obs}}=0.0560 \\
\mathrm{wR}_{\mathrm{obs}}=0.1408\end{array}$ \\
\hline $\mathrm{R}$ indices [all data] & $\begin{array}{l}\mathrm{R}_{\mathrm{all}}=0.0920 \\
\mathrm{wR}_{\mathrm{all}}=0.0887\end{array}$ & $\begin{array}{l}\mathrm{R}_{\mathrm{all}}=0.0406 \\
\mathrm{w}_{\mathrm{all}}=0.0779\end{array}$ & $\begin{array}{l}\mathrm{R}_{\mathrm{all}}=0.1082 \\
\mathrm{wR}_{\mathrm{all}}=0.1018\end{array}$ & $\begin{array}{l}\mathrm{R}_{\mathrm{all}}=0.0667 \\
\mathrm{wR}_{\mathrm{all}}=0.1470\end{array}$ \\
\hline $\begin{array}{l}\text { Largest diff. peak } \\
\text { and hole }\end{array}$ & $\begin{array}{l}1.83 \text { and }-2.18 \\
\mathrm{e} \cdot \AA^{-3}\end{array}$ & $\begin{array}{l}1.231 \text { and }-0.951 \\
\mathrm{e} \cdot \AA^{-3}\end{array}$ & $\begin{array}{l}3.65 \text { and }-3.40 \\
\mathrm{e} \cdot \AA^{-3}\end{array}$ & $\begin{array}{l}1.840 \text { and }-3.520 \\
\mathrm{e} \cdot \AA^{-3}\end{array}$ \\
\hline
\end{tabular}


Table 3. Bond Distances of the Double Perovskites. (Only Ag-I distances smaller than the sum of van der Waals radii are included here)

\begin{tabular}{|c|c|c|c|c|c|}
\hline \multicolumn{4}{|c|}{$(3 \mathrm{AMPY})_{2} \mathrm{AgBiI}_{8} \cdot \mathrm{H}_{2} \mathrm{O}$} & \multicolumn{2}{|c|}{$(4 \mathrm{AMP})_{2} \mathrm{AgBiI}_{8} \cdot 0.5 \mathrm{H}_{2} \mathrm{O}$} \\
\hline Label & Distance $(\AA)$ & Label & Distance $(\AA)$ & Label & Distance $(\AA)$ \\
\hline $\mathrm{Bi}(1)-\mathrm{I}(1)$ & $3.0631(14)$ & $\mathrm{I}(8)-\operatorname{Ag}(2) \# 2$ & $3.115(7)$ & $\mathrm{Bi}(1)-\mathrm{I}(2)$ & $3.1894(8)$ \\
\hline $\operatorname{Bi}(1)-\mathrm{I}(2)$ & $3.1226(17)$ & $\mathrm{I}(9)-\operatorname{Ag}(2)$ & $2.981(9)$ & $\operatorname{Bi}(1)-\mathrm{I}(3)$ & $3.1094(7)$ \\
\hline $\operatorname{Bi}(1)-\mathrm{I}(3)$ & $2.9836(15)$ & $\mathrm{I}(9)-\operatorname{Ag}(3)$ & $3.262(11)$ & $\operatorname{Bi}(1)-\mathrm{I}(4)$ & $2.9993(8)$ \\
\hline $\operatorname{Bi}(1)-\mathrm{I}(6)$ & $3.0408(17)$ & $\mathrm{I}(12)-\operatorname{Ag}(2)$ & $2.739(10)$ & $\mathrm{Bi}(1)-\mathrm{I}(5)$ & $3.0450(7)$ \\
\hline $\operatorname{Bi}(1)-\mathrm{I}(8)$ & $3.0881(14)$ & $\mathrm{I}(12)-\operatorname{Ag}(3)$ & $2.650(10)$ & $\operatorname{Bi}(1)-\mathrm{I}(7)$ & $2.9852(8)$ \\
\hline $\operatorname{Bi}(1)-\mathrm{I}(9)$ & $3.1632(16)$ & $\mathrm{I}(13)-\operatorname{Ag}(1)$ & $2.985(7)$ & $\operatorname{Bi}(1)-\mathrm{I}(8)$ & $3.2144(9)$ \\
\hline $\operatorname{Bi}(2)-\mathrm{I}(4)$ & $2.9830(16)$ & $\mathrm{I}(14)-\operatorname{Ag}(1)$ & $2.705(11)$ & Average & $3.0905(8)$ \\
\hline $\operatorname{Bi}(2)-I(5)$ & $3.0616(14)$ & $\mathrm{I}(14)-\operatorname{Ag}(4)$ & $2.636(14)$ & $\mathrm{I}(6)-\operatorname{Ag}(0 \mathrm{~A})$ & $2.7259(8)$ \\
\hline $\operatorname{Bi}(2)-\mathrm{I}(7)$ & $3.0873(15)$ & $\mathrm{I}(15)-\operatorname{Ag}(1)$ & $2.709(11)$ & $\mathrm{I}(9)-\operatorname{Ag}(1)$ & $2.6525(8)$ \\
\hline $\operatorname{Bi}(2)-\mathrm{I}(10)$ & $3.0411(17)$ & $\mathrm{I}(15)-\operatorname{Ag}(4)$ & $2.639(14)$ & $\operatorname{Ag}(1)-\mathrm{I}(9) \# 1$ & $2.6524(8)$ \\
\hline $\operatorname{Bi}(2)-I(11)$ & $3.1181(17)$ & $\mathrm{I}(16)-\operatorname{Ag}(2)$ & $2.717(10)$ & $\mathrm{Ag}(0 \mathrm{~A})-\mathrm{I}(6) \# 2$ & $2.7260(8)$ \\
\hline \multirow[t]{4}{*}{$\operatorname{Bi}(2)-\mathrm{I}(13)$} & $3.1656(16)$ & $\mathrm{I}(16)-\operatorname{Ag}(3)$ & $2.642(10)$ & & \\
\hline & & $\mathrm{I}(7) \# 2-\operatorname{Ag}(1)$ & $3.259(13)$ & & \\
\hline & & $\mathrm{I}(8) \# 1-\operatorname{Ag}(2)$ & $3.115(6)$ & & \\
\hline & & $\mathrm{I}(7)-\operatorname{Ag}(1) \# 1$ & $3.259(13)$ & & \\
\hline Average & $3.0766(16)$ & & $2.894(10)$ & & $2.6892(8)$ \\
\hline
\end{tabular}


Table 4. Bond Distances of the 1D Perovskites.

\begin{tabular}{|c|c|c|c|c|c|c|c|}
\hline \multicolumn{2}{|c|}{$(3 \mathrm{AMP}) \mathrm{BiI}_{5}$} & \multicolumn{2}{|c|}{$(4 \mathrm{AMP}) \mathrm{BiI}_{5}$} & \multicolumn{2}{|c|}{$(3 \mathrm{AMPY}) \mathrm{BiI}_{5}$} & \multicolumn{2}{|c|}{$(4 \mathrm{AMPY}) \mathrm{BiI}_{5}$} \\
\hline Label & Distance $(\AA)$ & Label & Distance $(\AA)$ & Label & Distance $(\AA)$ & Label & Distance $(\AA)$ \\
\hline $\operatorname{Bi}(1)-\mathrm{I}(1)$ & $3.079(3)$ & $\operatorname{Bi}(1)-\mathrm{I}(3)$ & $3.0232(10)$ & $\operatorname{Bi}(1)-\mathrm{I}(1)$ & $2.999(6)$ & $\operatorname{Bi}(1)-\mathrm{I}(2)$ & $3.1698(18)$ \\
\hline $\operatorname{Bi}(1)-I(4)$ & $2.946(7)$ & $\operatorname{Bi}(1)-I(4)$ & $3.2422(10)$ & $\operatorname{Bi}(1)-\mathrm{I}(2)$ & $3.058(3)$ & $\operatorname{Bi}(1)-\mathrm{I}(6)$ & $3.2660(19)$ \\
\hline $\operatorname{Bi}(1)-\mathrm{I}(6)$ & $2.927(7)$ & $\operatorname{Bi}(1)-\mathrm{I}(5)$ & $3.3240(10)$ & Bi(1)-I(3) & $2.909(7)$ & $\operatorname{Bi}(1)-\mathrm{I}(1)$ & $2.9752(18)$ \\
\hline $\operatorname{Bi}(1)-\mathrm{I}(7)$ & $3.224(12)$ & $\operatorname{Bi}(1)-\mathrm{I}(6)$ & $3.1725(11)$ & $\operatorname{Bi}(1)-\mathrm{I}(4)$ & $3.258(10)$ & $\operatorname{Bi}(1)-\mathrm{I}(5)$ & $2.9415(19)$ \\
\hline $\operatorname{Bi}(1)-\mathrm{I}(7) \# 1$ & $3.237(12)$ & Bi(1)-I(8) & $2.9491(10)$ & $\operatorname{Bi}(1)-\mathrm{I}(4) \# 1$ & $3.261(10)$ & $\operatorname{Bi}(1)-\mathrm{I}(3)$ & $3.248(2)$ \\
\hline $\operatorname{Bi}(1)-\mathrm{I}(10)$ & $3.088(4)$ & $\operatorname{Bi}(1)-\mathrm{I}(1)$ & $2.9069(10)$ & $\operatorname{Bi}(1)-\mathrm{I}(10)$ & $3.104(4)$ & $\operatorname{Bi}(1)-\mathrm{I}(4)$ & $2.961(2)$ \\
\hline $\operatorname{Bi}(2)-\mathrm{I}(2)$ & $2.952(7)$ & $\operatorname{Bi}(2)-\mathrm{I}(2)$ & $3.0243(10)$ & $\operatorname{Bi}(2)-\mathrm{I}(5)$ & $3.127(3)$ & $\operatorname{Bi}(2)-\mathrm{I}(6)$ & $3.2467(19)$ \\
\hline $\operatorname{Bi}(2)-\mathrm{I}(3)$ & $3.073(3)$ & $\mathrm{Bi}(2)-\mathrm{I}(4)$ & $3.3227(10)$ & Bi(2)-I(6) & $2.916(6)$ & Bi(2)-I(9) & $3.0416(19)$ \\
\hline $\operatorname{Bi}(2)-\mathrm{I}(5)$ & $2.931(7)$ & $\operatorname{Bi}(2)-\mathrm{I}(5) \# 1$ & $3.2415(10)$ & $\operatorname{Bi}(2)-\mathrm{I}(7)$ & $2.960(8)$ & $\operatorname{Bi}(2)-\mathrm{I}(8)$ & $3.0759(19)$ \\
\hline $\operatorname{Bi}(2)-\mathrm{I}(8)$ & $3.237(12)$ & $\operatorname{Bi}(2)-\mathrm{I}(7)$ & $3.1732(11)$ & Bi(2)-I(8) & $3.034(4)$ & $\operatorname{Bi}(2)-\mathrm{I}(3) \# 1$ & $3.253(2)$ \\
\hline $\operatorname{Bi}(2)-\mathrm{I}(8) \# 2$ & $3.231(12)$ & $\operatorname{Bi}(2)-\mathrm{I}(9)$ & $2.9489(10)$ & $\operatorname{Bi}(2)-\mathrm{I}(9)$ & $3.228(13)$ & $\operatorname{Bi}(2)-\mathrm{I}(10)$ & $2.949(2)$ \\
\hline $\operatorname{Bi}(2)-\mathrm{I}(9)$ & $3.089(4)$ & $\mathrm{Bi}(2)-\mathrm{I}(10)$ & $2.9053(10)$ & $\mathrm{Bi}(2)-\mathrm{I}(9) \# 3$ & $3.252(13)$ & $\operatorname{Bi}(2)-\mathrm{I}(7)$ & $2.959(2)$ \\
\hline Average & $3.084(8)$ & & $3.1028(10)$ & & $3.092(7)$ & & $3.0906(19)$ \\
\hline
\end{tabular}


Table 5. Bond Angles of the Compounds Reported Here.

\begin{tabular}{|c|c|c|c|}
\hline (3AMP)BiI 5 & $\operatorname{Angle}\left({ }^{\circ}\right)$ & $(3 \mathrm{AMPY})_{\mathrm{BiI}}$ & Angle $\left(^{\circ}\right)$ \\
\hline $\mathrm{Bi}(2)-\mathrm{I}(8)-\mathrm{Bi}(2) \# 7$ & $178.4(4)$ & $\mathrm{Bi}(1)-\mathrm{I}(4)-\mathrm{Bi}(1) \# 6$ & $179.5(3)$ \\
\hline $\operatorname{Bi}(1)-\mathrm{I}(7)-\mathrm{Bi}(1) \# 6$ & $178.7(5)$ & $\operatorname{Bi}(2)-\mathrm{I}(9)-\mathrm{Bi}(2) \# 7$ & $179.8(5)$ \\
\hline Average & $178.6(5)$ & Average & $179.7(4)$ \\
\hline$(4 \mathrm{AMP}) \mathrm{BiI}_{5}$ & Angle $\left({ }^{\circ}\right)$ & (4AMPY)BiI 5 & Angle $\left({ }^{\circ}\right)$ \\
\hline $\mathrm{Bi}(1)-\mathrm{I}(4)-\mathrm{Bi}(2)$ & $160.93(3)$ & $\mathrm{Bi}(2)-\mathrm{I}(6)-\mathrm{Bi}(1)$ & $156.64(8)$ \\
\hline $\operatorname{Bi}(2) \# 2-I(5)-\operatorname{Bi}(1)$ & $160.91(3)$ & $\operatorname{Bi}(1)-\mathrm{I}(3)-\mathrm{Bi}(2) \# 2$ & $157.58(7)$ \\
\hline Average & $160.92(3)$ & Average & $157.11(8)$ \\
\hline$(4 \mathrm{AMP})_{2} \mathrm{AgBiI}_{8} \cdot 0.5 \mathrm{H}_{2} \mathrm{O}$ & $\operatorname{Angle}\left({ }^{\circ}\right)$ & & Angle $\left(^{\circ}\right)$ \\
\hline $\operatorname{Bi}(1)-\mathrm{I}(3)-\operatorname{Ag}(0 \mathrm{~A})$ & $155.47(2)$ & $\mathrm{Bi}(1)-\mathrm{I}(2)-\mathrm{Ag}(0 \mathrm{~A})$ & $163.60(2)$ \\
\hline $\operatorname{Ag}(1)-\mathrm{I}(5)-\mathrm{Bi}(1)$ & $157.45(2)$ & $\operatorname{Bi}(1)-\mathrm{I}(7)-\operatorname{Ag}(1)$ & $177.11(2)$ \\
\hline Average & $163.41(2)$ & & \\
\hline
\end{tabular}




\section{TOC}

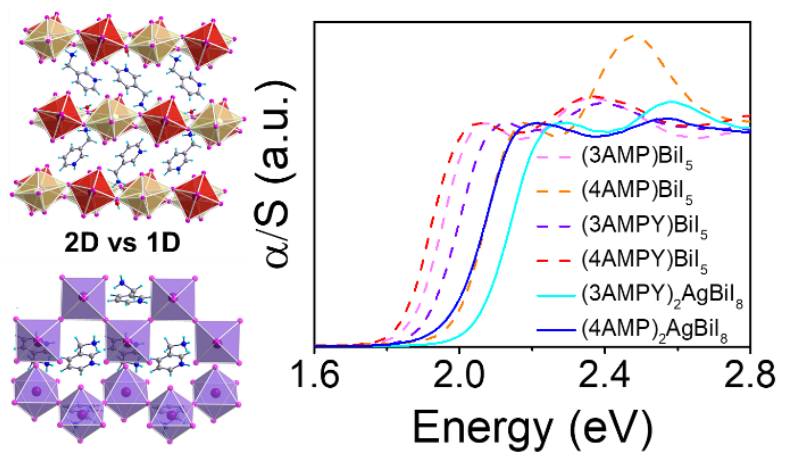

